Supporting Information for

\title{
Covalent Post-assembly Modification Triggers Structural Transformations of Borromean rings
}

\author{
Wen-Xi Gao ${ }^{a}$, Hui-Jun Fenga ${ }^{a}$ Yue-Jian Lin ${ }^{a}$ and Guo-Xin Jin ${ }^{a^{\star}}$
}

\begin{abstract}
a. Shanghai Key Laboratory of Molecular Catalysis and Innovative Materials, State Key Laboratory of Molecular Engineering of Polymers, Collaborative Innovation Center of Chemistry for Energy Materials, Department of Chemistry, Fudan University, Shanghai 200433, P. R. China.
\end{abstract}

*Email: gxjin@fudan.edu.cn. 


\section{Contents}

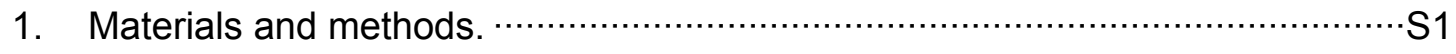

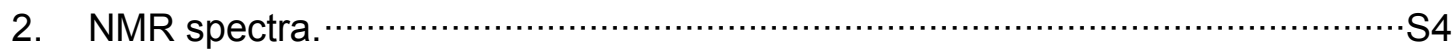

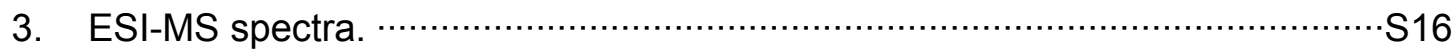

4. IEDDA reaction between tetrazine fragments and dienophiles. ……..............S2 21

5. Concentration-induced supramolecular structural transformation. ……...........S22

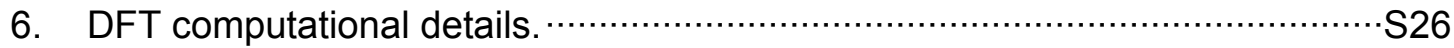

7. Single-crystal-to-single-crystal transformation experiment. …........................S28

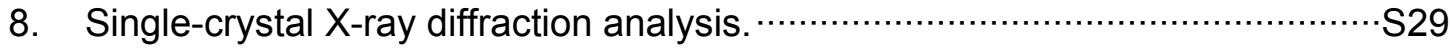

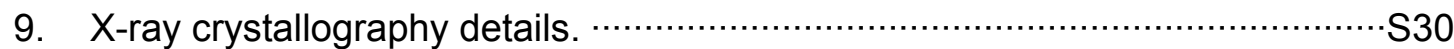

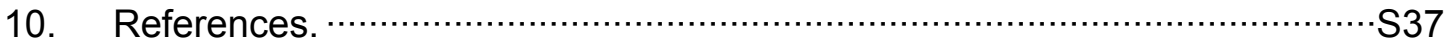




\section{Materials and methods.}

All reagents and solvents were purchased from commercial sources and used as supplied unless otherwise mentioned. The starting materials $\left[\mathrm{Cp}^{*} \mathrm{RhCl}_{2}\right]_{2} \quad\left(\mathrm{Cp}^{*}=\eta^{5_{-}}\right.$ pentamethylcyclopentadienyl) ${ }^{[\mathrm{S} 1]}, 3,6$-bis(4-pyridyl)-1,2,4,5-tetrazine (bptz) ${ }^{[\mathrm{S} 2]}, \mathrm{Na}_{2}[\mathrm{Cu} \text { (opba) }]^{[\mathrm{S} 3]}$ were prepared by the literature method. Celite ${ }^{\circledR}$ refers to diatomaceous earth (powder, suitable for most filtrations) and was obtained from Sigma Aldrich. NMR spectra were recorded on Bruker AVANCE I 400 at room temperature and referenced to the residual protonated solvent for NMR spectra. Proton chemical shift $\delta \mathrm{H}=1.94\left(\mathrm{CD}_{3} \mathrm{CN}\right), \delta \mathrm{H}=3.31\left(\mathrm{CD}_{3} \mathrm{OD}\right)$ are reported relative to the solvent residual peak. Elemental analyses were performed on an Elementar Vario EL III analyzer. IR spectra of the solid samples (KBr tablets) in the range $400-4000 \mathrm{~cm}^{-1}$ were recorded on a Nicolet AVATAR-360IR spectrometer. HR-ESI-MS spectra were recorded on a Micro TOF II mass spectrometer using electrospray ionization.

\subsection{Synthesis of $\mathbf{1}$.}

$\operatorname{AgOTf}(25.7 \mathrm{mg}, 0.1 \mathrm{mmol})$ was added to a solution of $\left[\mathrm{Cp}^{*} \mathrm{RhCl}_{2}\right]_{2}(62.0 \mathrm{mg}, 0.1 \mathrm{mmol})$ in $\mathrm{CH}_{3} \mathrm{OH}(10 \mathrm{~mL})$ at room temperature. The reaction mixture was stirred in the dark for $6 \mathrm{~h}$ and then filtered, followed by addition of 3,6-bis(4-pyridyl)-1,2,4,5-tetrazine (BPTZ) (23.6 mg, $0.1 \mathrm{mmol}$ ). After stirring for another $12 \mathrm{~h}$ at room temperature, the reaction mixture was concentrated to a volume of $3 \mathrm{~mL}$ under reduced pressure, filtered through Celite and recrystallized by slow diffusion of diethyl ether into the filtrate. An orange crystalline solid $(100.7 \mathrm{mg})$ was obtained in $93.1 \%$ yield. ${ }^{1} \mathrm{H}$ NMR $\left(400 \mathrm{MHz}, d_{3}-\mathrm{CD}_{3} \mathrm{CN}, \mathrm{ppm}\right) \delta=8.36(\mathrm{dd}, 16 \mathrm{H}), 1.59$ (s, 60H). IR $\left(\mathrm{KBr} \mathrm{cm}^{-1}\right): 3451,2920$, $1615,1453,1425,1393,1263,1225,1161,1059,1031,638,605,574,518$. Elemental analysis calcd (\%) for $\mathrm{C}_{68} \mathrm{H}_{76} \mathrm{Cl}_{4} \mathrm{~F}_{12} \mathrm{~N}_{12} \mathrm{O}_{12} \mathrm{Rh}_{4} \mathrm{~S}_{4}$ : C, 37.76; H, 3.54; N, 7.77; found: C, 37.52; H, 3.54; N, 7.59. ESI-MS: $\mathrm{m} / \mathrm{z}=932.0153$ (calcd for $[\mathrm{M}-2 \mathrm{OTf}]^{2+}$ 932.0153).

\subsection{Synthesis of 2.}

2,5-norbornadiene (NBD, $20.3 \mu \mathrm{L}, 0.2 \mathrm{mmol})$ was added to a solution of complex $\mathbf{1}(108.2 \mathrm{mg}$, $0.05 \mathrm{mmol})$ in $\mathrm{CH}_{3} \mathrm{CN}(10 \mathrm{~mL})$ at room temperature. After stirring for $6 \mathrm{~h}$ at room temperature, the solvent was concentrated to about $3 \mathrm{~mL}$ and diethyl ether was added, to give $\mathbf{2}$ as yellow solid (yield: $94.0 \mathrm{mg}, 85.7$ \%). ${ }^{1} \mathrm{H}$ NMR (400 MHz, $\left.d_{3}-\mathrm{CD}_{3} \mathrm{CN}, \mathrm{ppm}\right) \delta=8.16(\mathrm{~d}, 8 \mathrm{H}), 8.12(\mathrm{~s}, 4 \mathrm{H}), 8.08(\mathrm{~d}, 8 \mathrm{H})$, 1.57 (s, 60H). IR ( $\left.\mathrm{KBr} \mathrm{cm}^{-1}\right)$ : 3493, 3101, 2973, 2920, 1616, 1573, 1453, 1429, 1405, 1378, 1259, 1225 , 1161, 1061, 1031, 827, 757, 731, 639, 591, 574, 518, 457. Elemental analysis calcd (\%) for $\mathrm{C}_{72} \mathrm{H}_{80} \mathrm{Cl}_{4} \mathrm{~F}_{12} \mathrm{~N}_{8} \mathrm{O}_{12} \mathrm{Rh}_{4} \mathrm{~S}_{4}: \mathrm{C}, 40.05 ; \mathrm{H}, 3.73 ; \mathrm{N}, 5.19$; found: $\mathrm{C}, 40.16 ; \mathrm{H}, 3.79 ; \mathrm{N}, 5.34$. ESI-MS: $\mathrm{m} / \mathrm{z}=$ 930.0263 (calcd for $[\mathrm{M}-2 \mathrm{OTf}]^{2+}$ 930.0249).

\subsection{Synthesis of $\mathbf{3}$.}

Sodium naphthazarin $\mathrm{Na}_{2} \mathbf{L}^{\mathbf{1}}$ (23.4 $\left.\mathrm{mg}, 0.1 \mathrm{mmol}\right)$ was added to a solution of complex $\mathbf{1}$ (108.2 $\mathrm{mg}, 0.05 \mathrm{mmol})$ in $\mathrm{CH}_{3} \mathrm{CN}(3 \mathrm{~mL})$, and the suspension was stirred at room temperature for $12 \mathrm{~h}$, the filtrate was recrystallized by slow diffusion of diisopropyl ether into the filtrate. A green crystalline solid ( $105 \mathrm{mg}$ ) was obtained in $87.6 \%$ yield. 3-BR: ${ }^{1} \mathrm{H}$ NMR $\left(400 \mathrm{MHz}, d_{3}-\mathrm{CD}_{3} \mathrm{CN}, \mathrm{ppm}\right) \delta=9.36(\mathrm{~d}$, 8H), 7.94 (d, 8H), 6.32 (s, 8H), 1.66 (s, 60H). IR ( $\mathrm{KBr} \mathrm{cm}^{-1}$ ): 3444, 1617, 1534, 1417, 1270, 1225, 1159, $1031,963,854,639,574,518$, 448. Elemental analysis calcd (\%) for $\mathrm{C}_{264} \mathrm{H}_{252} \mathrm{~F}_{36} \mathrm{~N}_{36} \mathrm{O}_{60} \mathrm{Rh}_{12} \mathrm{~S}_{12}: \mathrm{C}, 44.09$; 
H, 3.53; N, 7.01; found: C, 43.74; H, 3.67; N 7.35. ESI-MS: $\mathrm{m} / \mathrm{z}=2248.1334$ (calcd for [M - 3OTf] ${ }^{3+}$ 2248.1333). 3-MONO: ${ }^{1} \mathrm{H}$ NMR (400 MHz, $\left.d_{3}-\mathrm{CD}_{3} \mathrm{CN}, \mathrm{ppm}\right) \delta=8.64(\mathrm{~d}, 8 \mathrm{H}), 8.48(\mathrm{~d}, 8 \mathrm{H}), 7.21(\mathrm{~s}$, $8 \mathrm{H}), 1.56(\mathrm{~s}, 60 \mathrm{H})$.

\subsection{Synthesis of 4 .}

2,5-norbornadiene (NBD, $24.4 \mu \mathrm{L}, 0.24 \mathrm{mmol}$ ) was added to a solution of complex 3 (143.9 $\mathrm{mg}$, $0.02 \mathrm{mmol})$ in $\mathrm{CH}_{3} \mathrm{CN}(10 \mathrm{~mL})$ at room temperature. After stirring for $12 \mathrm{~h}$ at room temperature, the solvent was concentrated to about $3 \mathrm{~mL}$ and diethyl ether was added, to give 4 as yellow solid (yield: $94.0 \mathrm{mg}, 85.7 \%$ ). ${ }^{1} \mathrm{H}$ NMR $\left(400 \mathrm{MHz}, d_{3}-\mathrm{CD}_{3} \mathrm{CN}, \mathrm{ppm}\right) \delta=8.51(\mathrm{~d}, 8 \mathrm{H}), 8.18(\mathrm{~m}, 12 \mathrm{H}), 7.20(\mathrm{~s}, 8 \mathrm{H})$, 1.55 (s, 60H). IR ( $\left.\mathrm{KBr} \mathrm{cm}^{-1}\right): 3489,3054,2920,1614,1534,1417,1270,1225,1159,1031,963,825$, 638, 574, 518, 445. Elemental analysis calcd (\%) for $\mathrm{C}_{92} \mathrm{H}_{88} \mathrm{~F}_{12} \mathrm{~N}_{8} \mathrm{O}_{20} \mathrm{Rh}_{4} \mathrm{~S}_{4}$ : C, 46.17; H, 3.71; N, 4.68; found: C, 46.28; H, 3.93; N 3.53.

\subsection{Synthesis of $\mathbf{5}$.}

$\operatorname{AgOTf}(51.4 \mathrm{mg}, 0.2 \mathrm{mmol})$ was added to a solution of [Cp* $\left.\mathrm{RhCl}_{2}\right]_{2}(62 \mathrm{mg}, 0.1 \mathrm{mmol})$ in $\mathrm{CH}_{3} \mathrm{OH}(10 \mathrm{~mL})$, and the suspension was stirred at room temperature for $6 \mathrm{~h}$, followed by addition of $\mathrm{K}_{2}[\mathrm{Pd}(\mathrm{opba})]$ ( $43.2 \mathrm{mg}, 0.1 \mathrm{mmol}$ ) stirred for 6 h. 3,6-bis(4-pyridyl)-1,2,4,5-tetrazine (bpytz) (23.6 $\mathrm{mg}, 0.1 \mathrm{mmol}$ ) was then added to the filtrate. After the solution was stirred at room temperature for another $12 \mathrm{~h}$, the reaction mixture was concentrated to a volume of $3 \mathrm{~mL}$ under reduced pressure, filtered through Celite and recrystallized by slow diffusion of diethyl ether into the filtrate. An orange crystalline solid $(116 \mathrm{mg})$ was obtained in $85.2 \%$ yield. ${ }^{1} \mathrm{H}$ NMR $\left(400 \mathrm{MHz}, d_{3}\right.$ - $\left.\mathrm{CD}_{3} \mathrm{CN}, \mathrm{ppm}\right)$ $\delta=9.15(\mathrm{~d}, 6 \mathrm{H}), 9.07(\mathrm{~d}, 6 \mathrm{H}), 9.02(\mathrm{~d}, 6 \mathrm{H}), 8.74(\mathrm{~m}, 6 \mathrm{H}), 8.71(\mathrm{~d}, 6 \mathrm{H}), 8.49(\mathrm{~m}, 6 \mathrm{H}), 8.06(\mathrm{~d}, 6 \mathrm{H}), 7.69$ (d, 6H), $7.58(\mathrm{~m}, 6 \mathrm{H}), 7.47(\mathrm{~m}, 6 \mathrm{H}), 6.77$ (t, 6H), 6.49 (t, 6H), $1.80(\mathrm{~s}, 90 \mathrm{H}), 1.71(\mathrm{~s}, 90 \mathrm{H}) . \mathrm{IR}(\mathrm{KBr}$ $\mathrm{cm}^{-1}$ ): 3444, 1613, 1584, 1425, 1386, 1263, 1162, 1032, 758, 639, 602. Elemental analysis calcd (\%) for $\mathrm{C}_{264} \mathrm{H}_{252} \mathrm{~F}_{36} \mathrm{~N}_{48} \mathrm{O}_{72} \mathrm{Pd}_{6} \mathrm{Rh}_{12} \mathrm{~S}_{12}: \mathrm{C}, 38.71 ; \mathrm{H}, 3.10 ; \mathrm{N}, 8.21$; found: C, 38.80; H, 3.22; N 8.37. ESI-MS: $\mathrm{m} / \mathrm{z}$ $=2581.2666\left(\right.$ calcd for $[\mathrm{M}-3 \mathrm{OTf}]^{3+}$ 2581.2674), $1989.7128\left(\right.$ calcd for $\left.[\mathrm{M}-4 \mathrm{OTf}]^{4+} 1989.7124\right)$, 1489.1831 (calcd for $[\mathrm{M}-5 \mathrm{OTf}]^{5+}$ 1489.1794).

\subsection{Synthesis of 6.}

2,5-norbornadiene (NBD, $24.4 \mu \mathrm{L}, 0.24 \mathrm{mmol}$ ) was added to a solution of complex $\mathbf{5}(163.8 \mathrm{mg}$, $0.02 \mathrm{mmol})$ in $\mathrm{CH}_{3} \mathrm{CN}(10 \mathrm{~mL})$ at room temperature. After stirring for $24 \mathrm{~h}$ at $323 \mathrm{~K}$, the solvent was concentrated to about $3 \mathrm{~mL}$ and diethyl ether was added, to give $\mathbf{6}$ as light yellow solid in $83.1 \%$ yield $\left(113.3 \mathrm{mg}\right.$ ). ${ }^{1} \mathrm{H}$ NMR (400 MHz, $\left.d_{3}-\mathrm{CD}_{3} \mathrm{CN}, \mathrm{ppm}\right) \delta=9.16(\mathrm{br}, 12 \mathrm{H}), 9.01(\mathrm{~s}, 6 \mathrm{H}), 8.89(\mathrm{~s}, 6 \mathrm{H}), 8.51(\mathrm{~s}$, 6H), $7.96(\mathrm{~d}, 6 \mathrm{H}), 7.80(\mathrm{~d}, 6 \mathrm{H}), 7.75(\mathrm{~d}, 6 \mathrm{H}), 7.37(\mathrm{~s}, 6 \mathrm{H}), 7.09(\mathrm{~s}, 6 \mathrm{H}), 6.65(\mathrm{t}, 6 \mathrm{H}), 6.50(\mathrm{t}, 6 \mathrm{H}), 6.18$ (d, 6H), 5.44 (d, 6H), 1.80 (s, 90H), 1.71 (s, 90H). IR ( $\left.\mathrm{KBr} \mathrm{cm}^{-1}\right): 3444,3291,2969,1617,1473,1273$, 1224, 1148, 1031, 637, 572, 517, 457. Elemental analysis calcd (\%) for $\mathrm{C}_{264} \mathrm{H}_{252} \mathrm{~F}_{36} \mathrm{~N}_{48} \mathrm{O}_{72} \mathrm{Pd}_{6} \mathrm{Rh}_{12} \mathrm{~S}_{12}: \mathrm{C}$, $38.71 ; \mathrm{H}, 3.10 ; \mathrm{N}, 8.21$; found: $\mathrm{C}, 38.80 ; \mathrm{H}, 3.22 ; \mathrm{N}$ 8.37. ESI-MS: $\mathrm{m} / \mathrm{z}=2577.2870$ (calcd for $[\mathrm{M}-$ 3OTf $]^{3+}$ 2577.2866), 1895.7261 (calcd for $[\mathrm{M}-4 \mathrm{OTf}]^{4+}$ 1895.7268), 1486.7882 (calcd for $[\mathrm{M}-$ 5OTf $\left.]^{5+} 1486.7910\right)$.

\subsection{Synthesis of 7.}

$\left[\mathrm{Cp}^{*} \mathrm{RhCl}_{2}\right]_{2}(62 \mathrm{mg}, 0.1 \mathrm{mmol})$ was added to a solution of chloranilic acid $(21 \mathrm{mg}, 0.1 \mathrm{mmol})$ 
and $\mathrm{MeONa}(10.8 \mathrm{mg}, 0.2 \mathrm{mmol})$ in $\mathrm{CH}_{3} \mathrm{OH}(10 \mathrm{~mL})$, and the suspension was stirred at room temperature for $6 \mathrm{~h}$, followed by addition of $\operatorname{AgOTf}(51.4 \mathrm{mg}, 0.2 \mathrm{mmol})$ stirred for $3 \mathrm{~h}$. 3,6-bis(4pyridyl)-1,2,4,5-tetrazine (bptz) $(23.6 \mathrm{mg}, 0.1 \mathrm{mmol})$ was then added to the filtrate. After the solution was stirred at room temperature for another $12 \mathrm{~h}$, the reaction mixture was concentrated to a volume of $3 \mathrm{~mL}$ under reduced pressure, filtered through Celite and recrystallized by slow diffusion of diethyl ether into the filtrate. A brown crystalline solid (108 mg) was obtained in $89.0 \%$ yield. ${ }^{1} \mathrm{H}$ NMR ( $\left.400 \mathrm{MHz}, d_{3}-\mathrm{CD}_{3} \mathrm{CN}, \mathrm{ppm}\right) \delta=8.41(\mathrm{~d}, 8 \mathrm{H}), 8,26(\mathrm{~d}, 8 \mathrm{H}), 1.65(\mathrm{~s}, 60 \mathrm{H})$. IR $\left(\mathrm{KBr} \mathrm{cm}^{-}\right.$ 1): 3449, 2926, 1617, 1514, 1496, 1374, 1263, 1225, 1155, 1032, 822, 639, 574, 518. Elemental analysis calcd (\%) for $\mathrm{C}_{264} \mathrm{H}_{252} \mathrm{~F}_{36} \mathrm{~N}_{36} \mathrm{O}_{60} \mathrm{Rh}_{12} \mathrm{~S}_{12}$ : C, 44.09; H, 3.53; N, 7.01; found: C, 43.74; H, 3.67; N 7.35. 
2. NMR spectra.
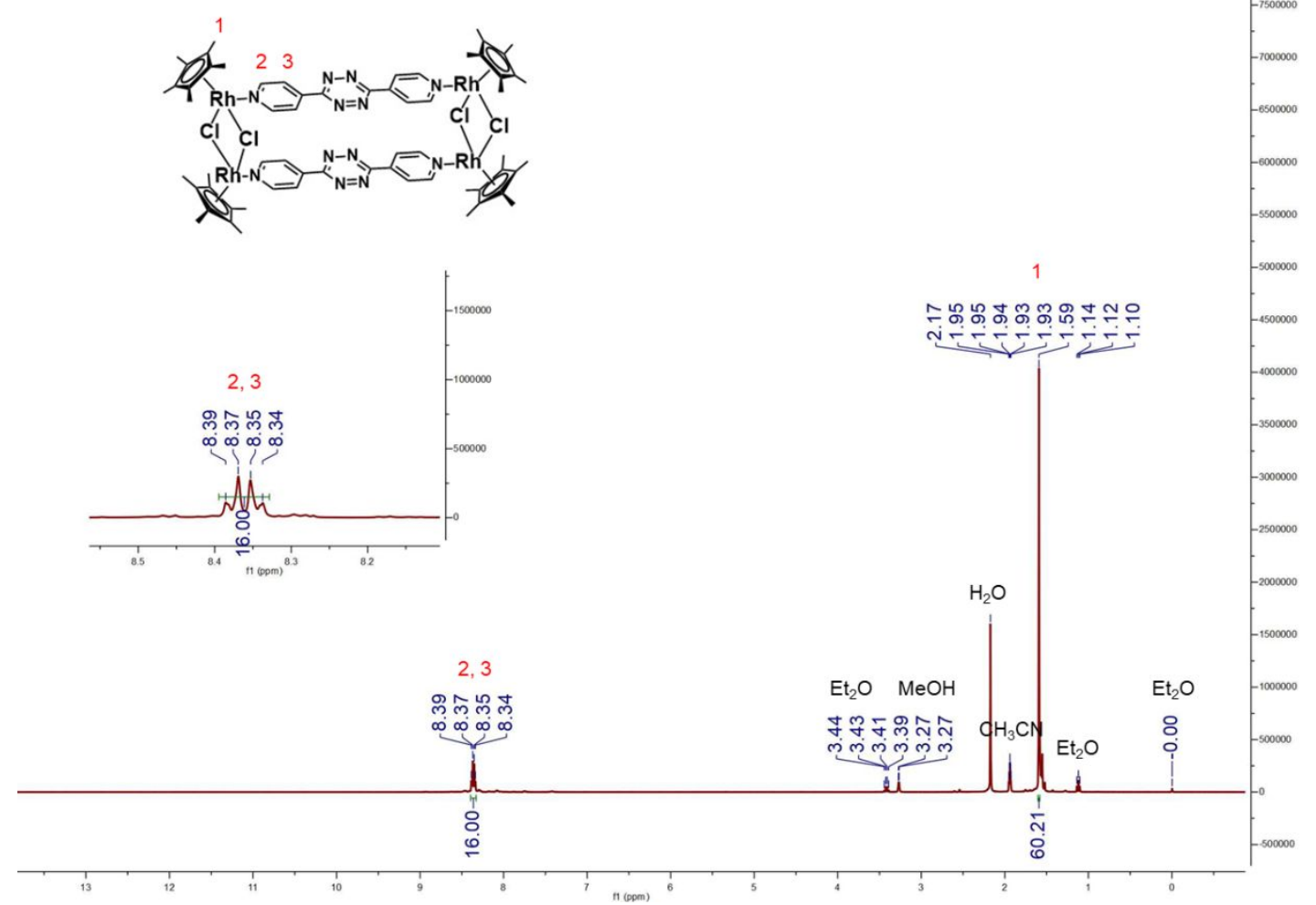

Figure S1. ${ }^{1} \mathrm{H}$ NMR (400 MHz, $\mathrm{CD}_{3} \mathrm{CN}$, ppm) for $\mathbf{1}$.

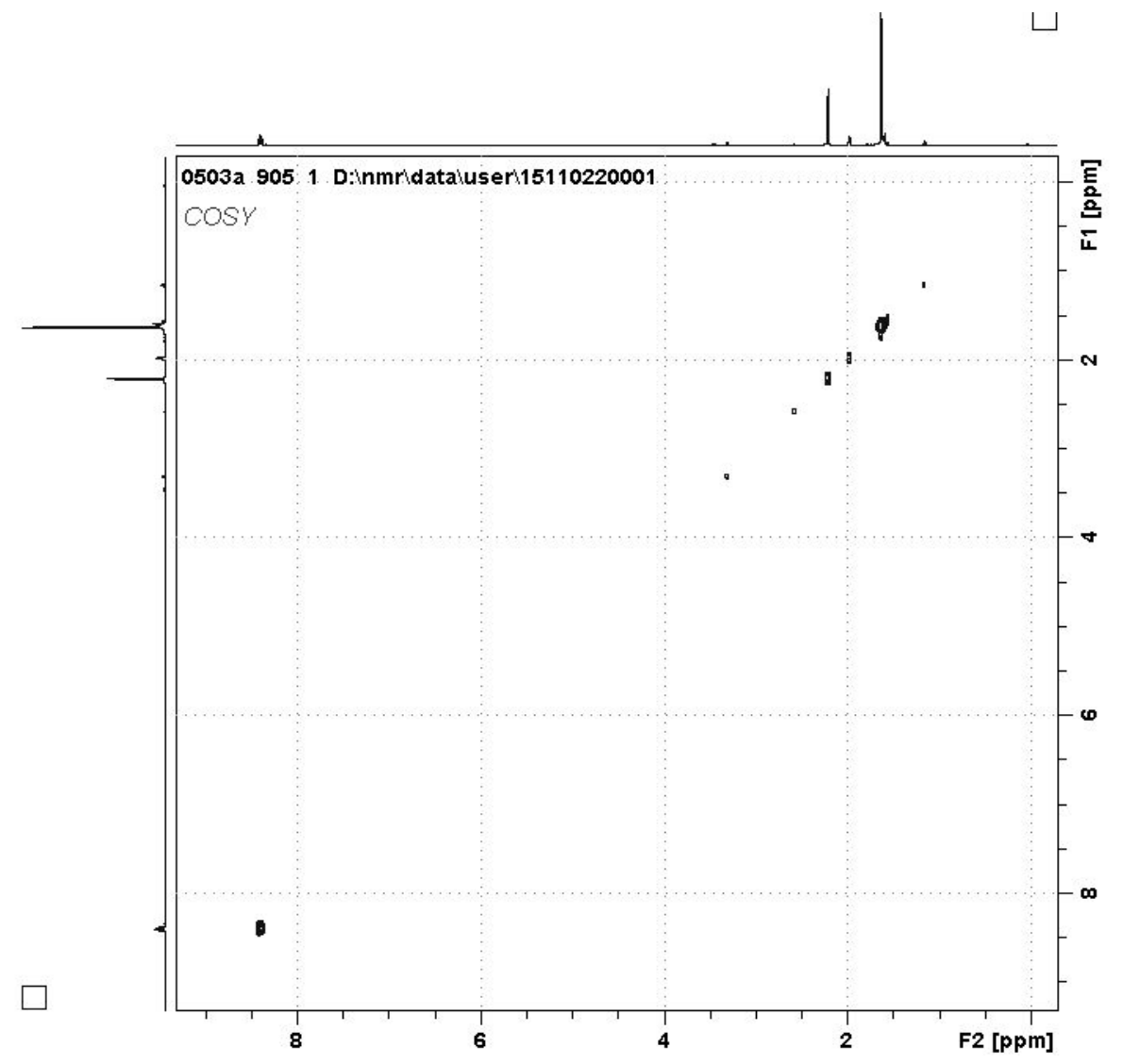


Figure S2. ${ }^{1} \mathrm{H}-{ }^{1} \mathrm{H}$ COSY NMR (400 MHz, $\mathrm{CD}_{3} \mathrm{CN}$, ppm) for $\mathbf{1}$.

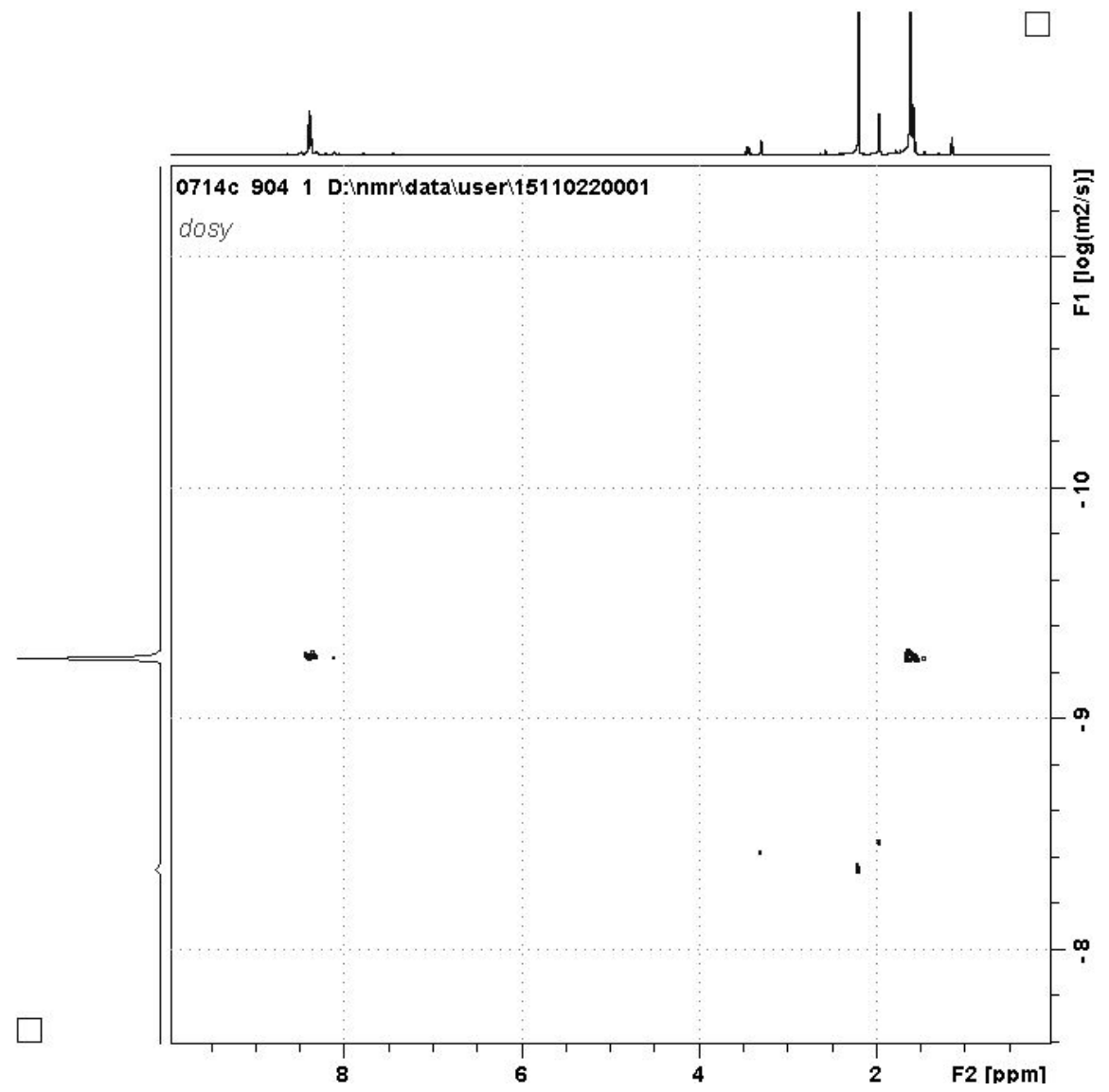

Figure S3. ${ }^{1} \mathrm{H}$ DOSY NMR (400 MHz, $\mathrm{CD}_{3} \mathrm{CN}$, ppm) for 1 . 

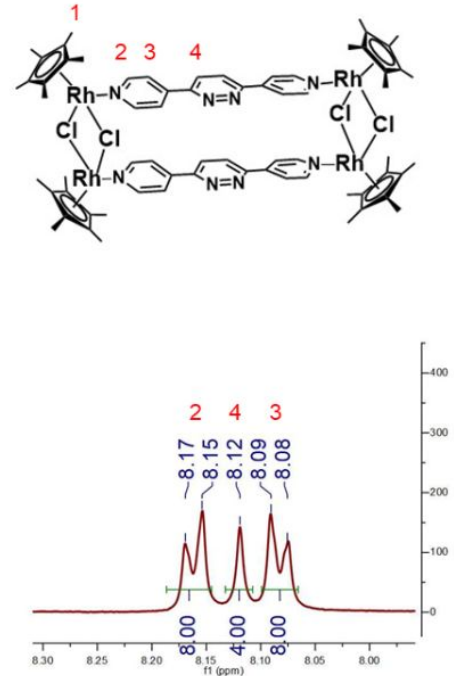

$2,3,4$ $\leqslant ㄴ ㅡ ㅇ ㅛ$

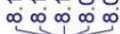

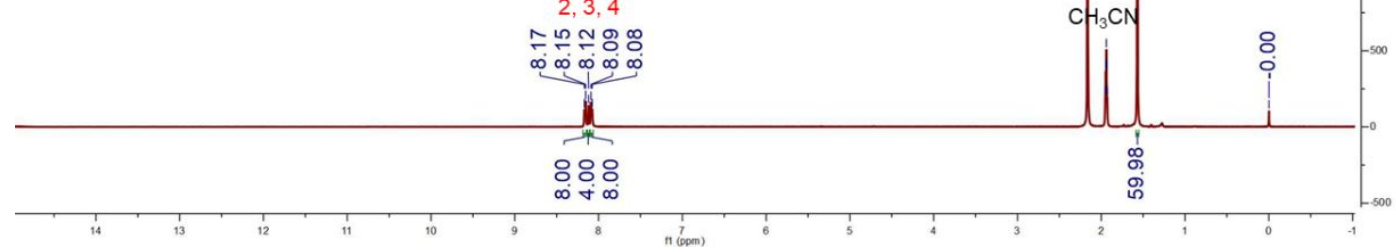

Figure S4. ${ }^{1} \mathrm{H}$ NMR (400 MHz, $\mathrm{CD}_{3} \mathrm{CN}$, ppm) for 2.

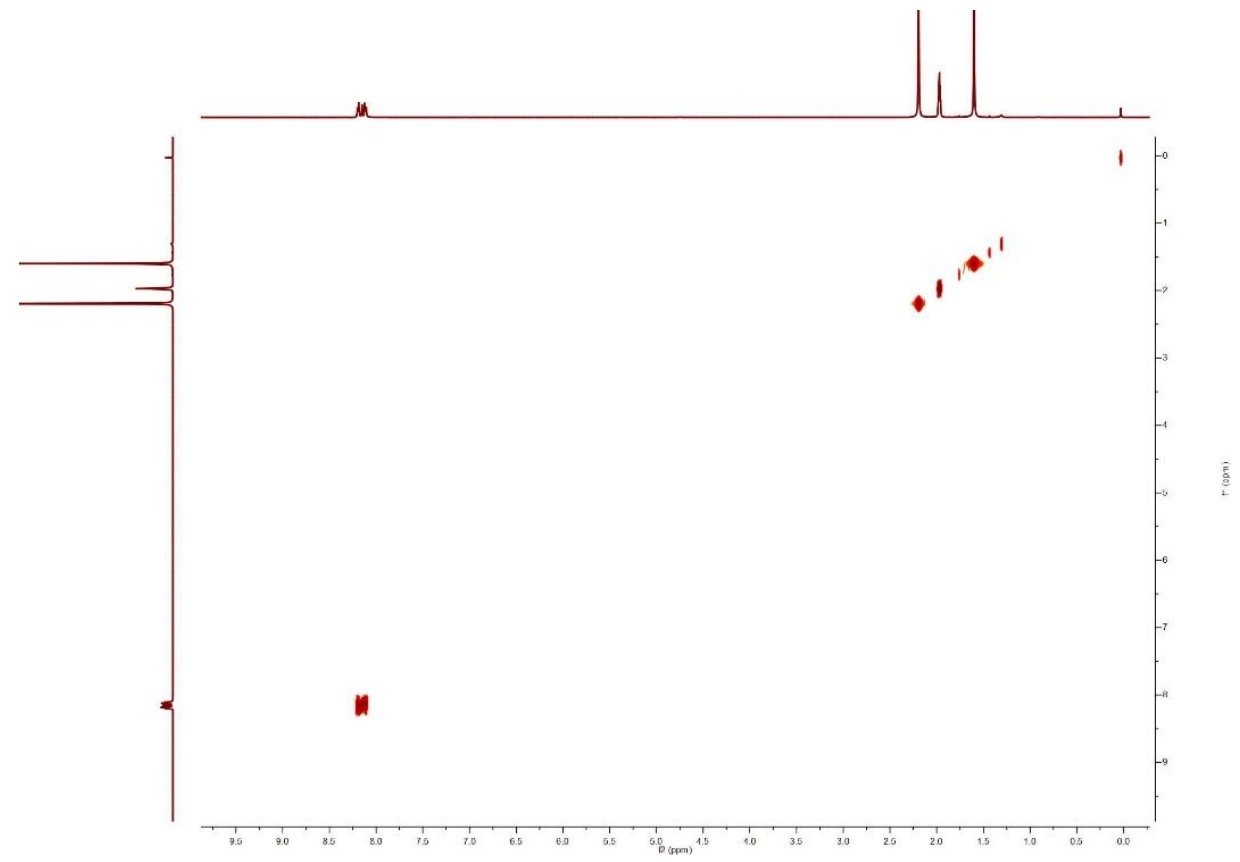

Figure S5. ${ }^{1} \mathrm{H}-{ }^{1} \mathrm{H}$ COSY NMR (400 MHz, $\mathrm{CD}_{3} \mathrm{CN}$, ppm) for 2. 


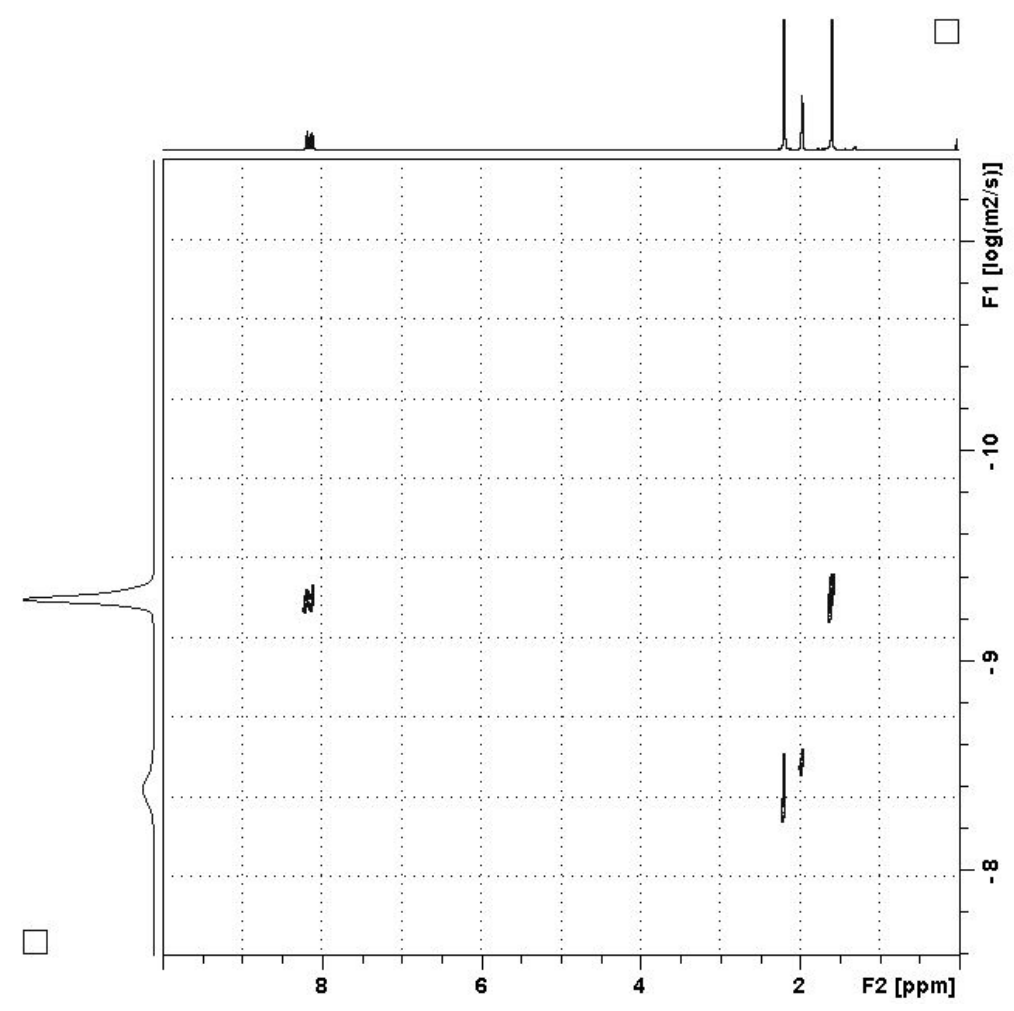

Figure S6. ${ }^{1} \mathrm{H}$ DOSY NMR (400 MHz, $\mathrm{CD}_{3} \mathrm{CN}$, ppm) for 2.
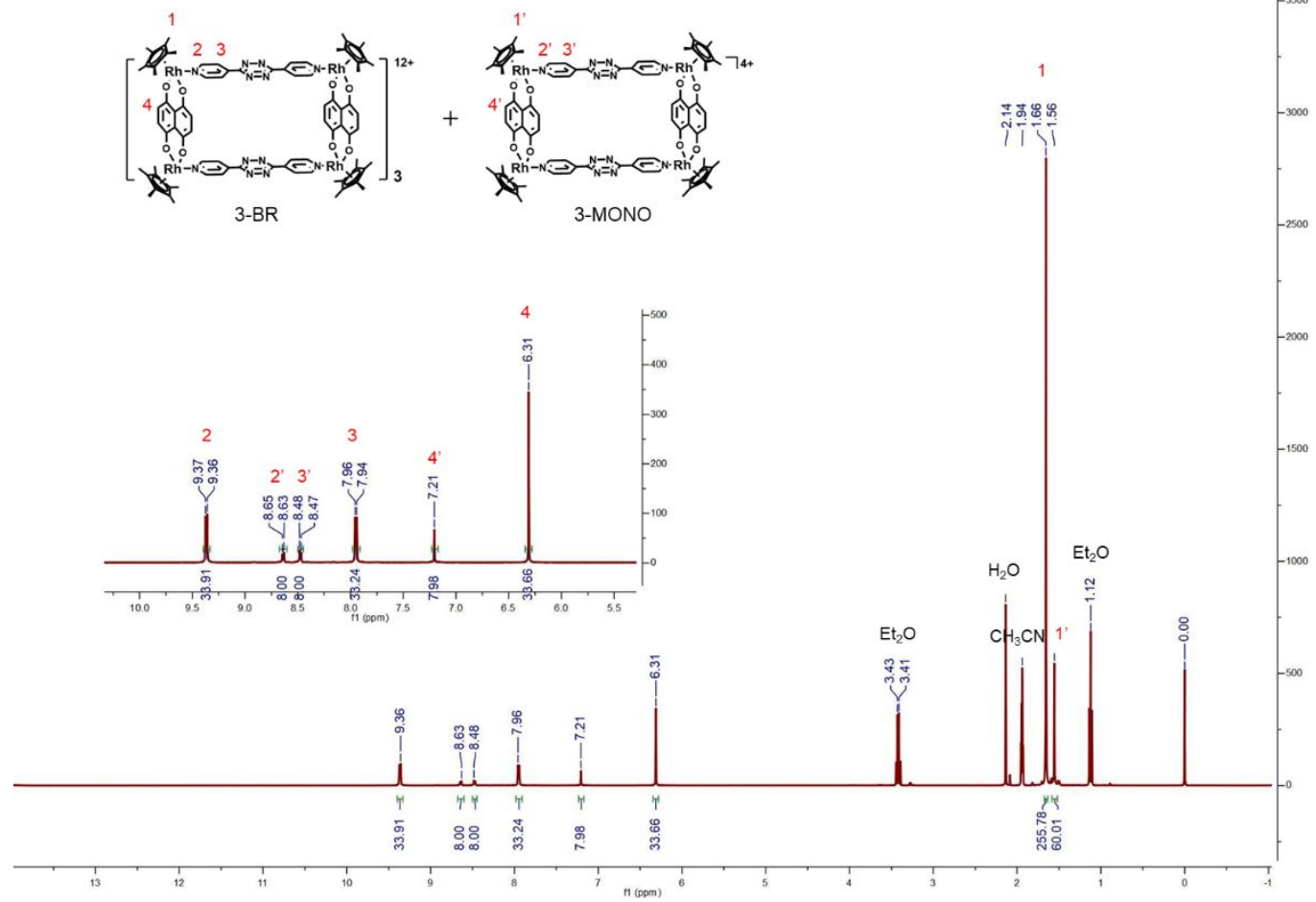

Figure S7. ${ }^{1} \mathrm{H}$ NMR (400 MHz, $\left.\mathrm{CD}_{3} \mathrm{CN}, \mathrm{ppm}\right)$ for $3(5 \mathrm{mM})$. 


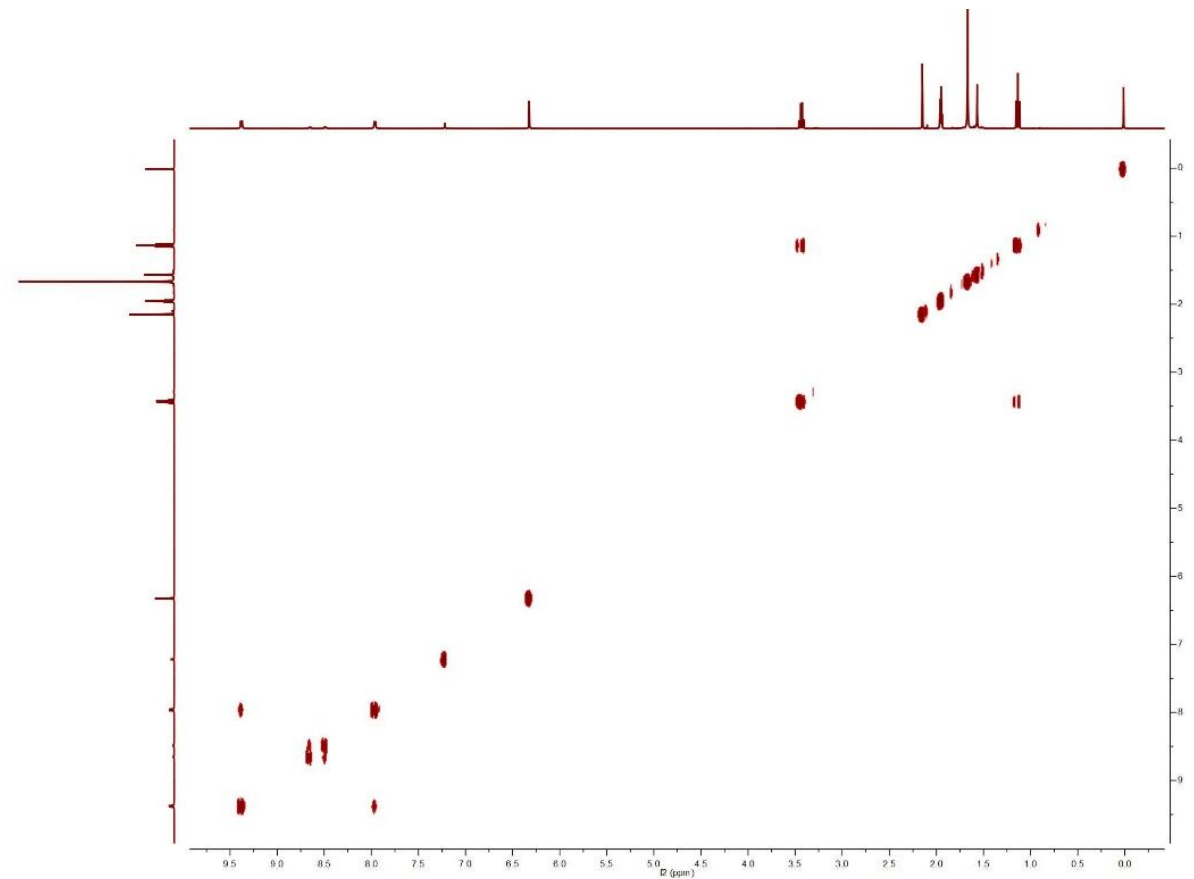

Figure S8. ${ }^{1} \mathrm{H}-{ }^{1} \mathrm{H}$ COSY NMR (400 MHz, $\mathrm{CD}_{3} \mathrm{CN}$, ppm) for $3(5 \mathrm{mM})$.

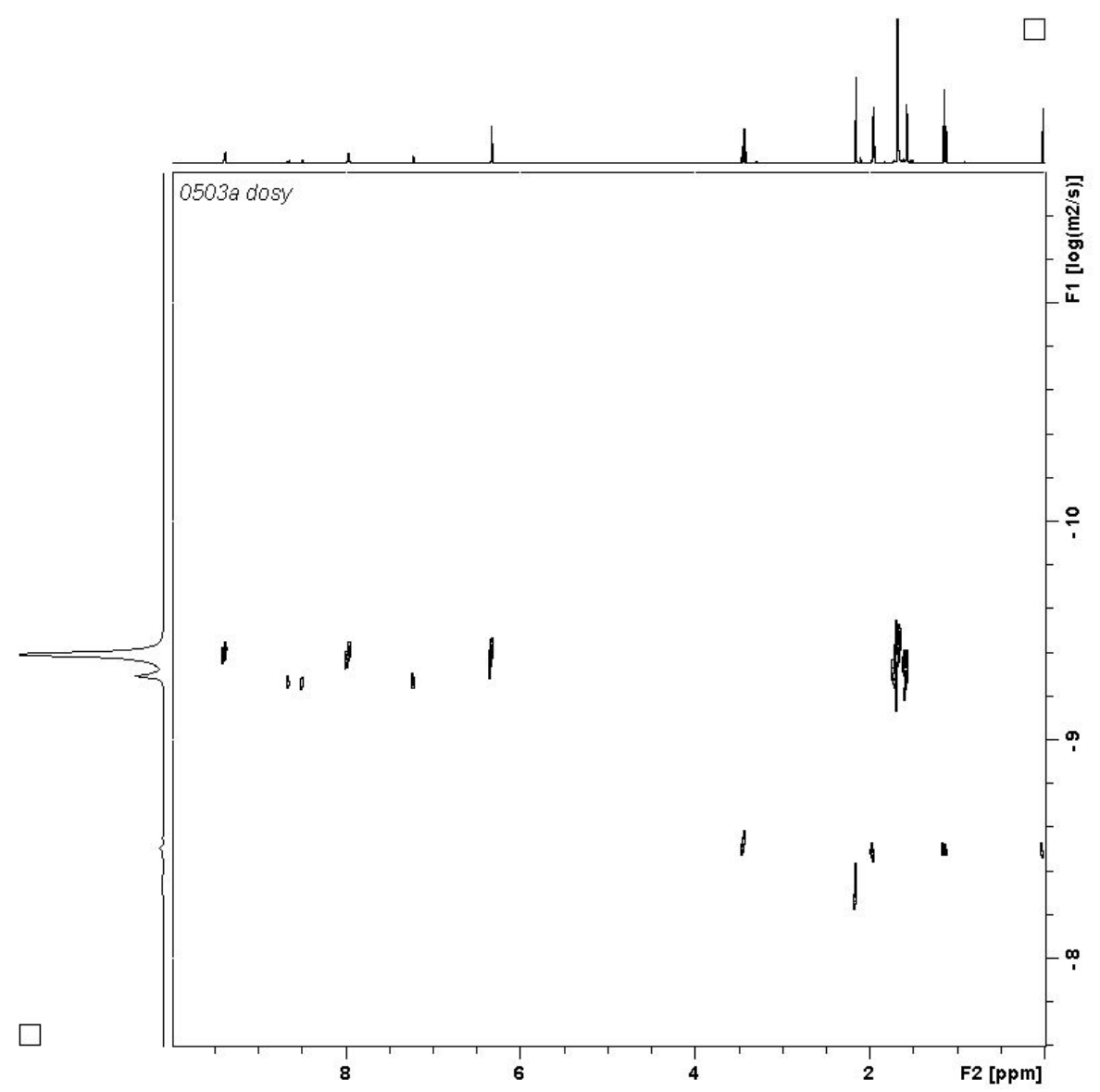

Figure S9. ${ }^{1} \mathrm{H}$ DOSY NMR (400 MHz, $\mathrm{CD}_{3} \mathrm{CN}$, ppm) for $3(5 \mathrm{mM})$. 

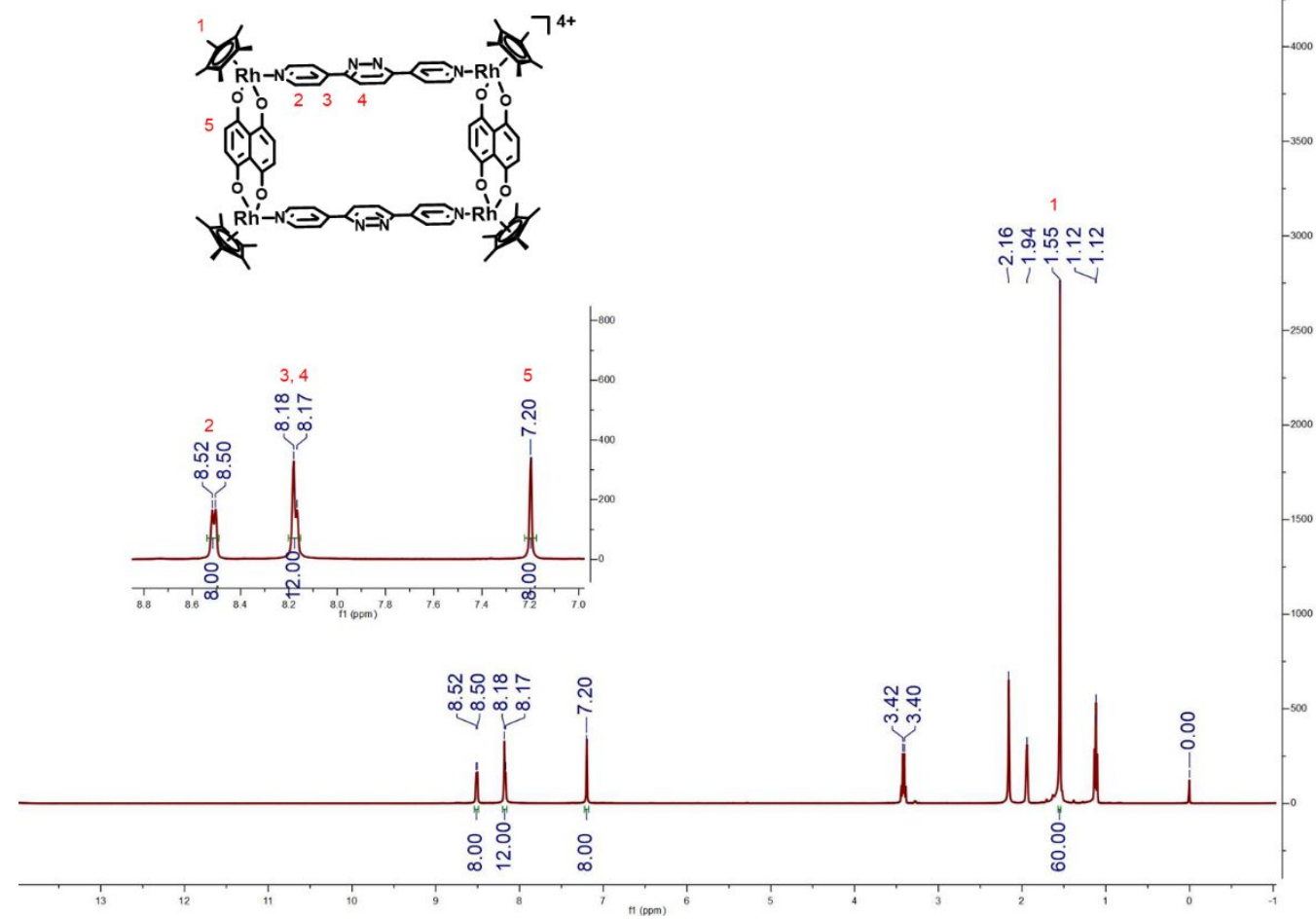

Figure S10. ${ }^{1} \mathrm{H}$ NMR $\left(400 \mathrm{MHz}, \mathrm{CD}_{3} \mathrm{CN}\right.$, ppm) for $4(8 \mathrm{mM})$.

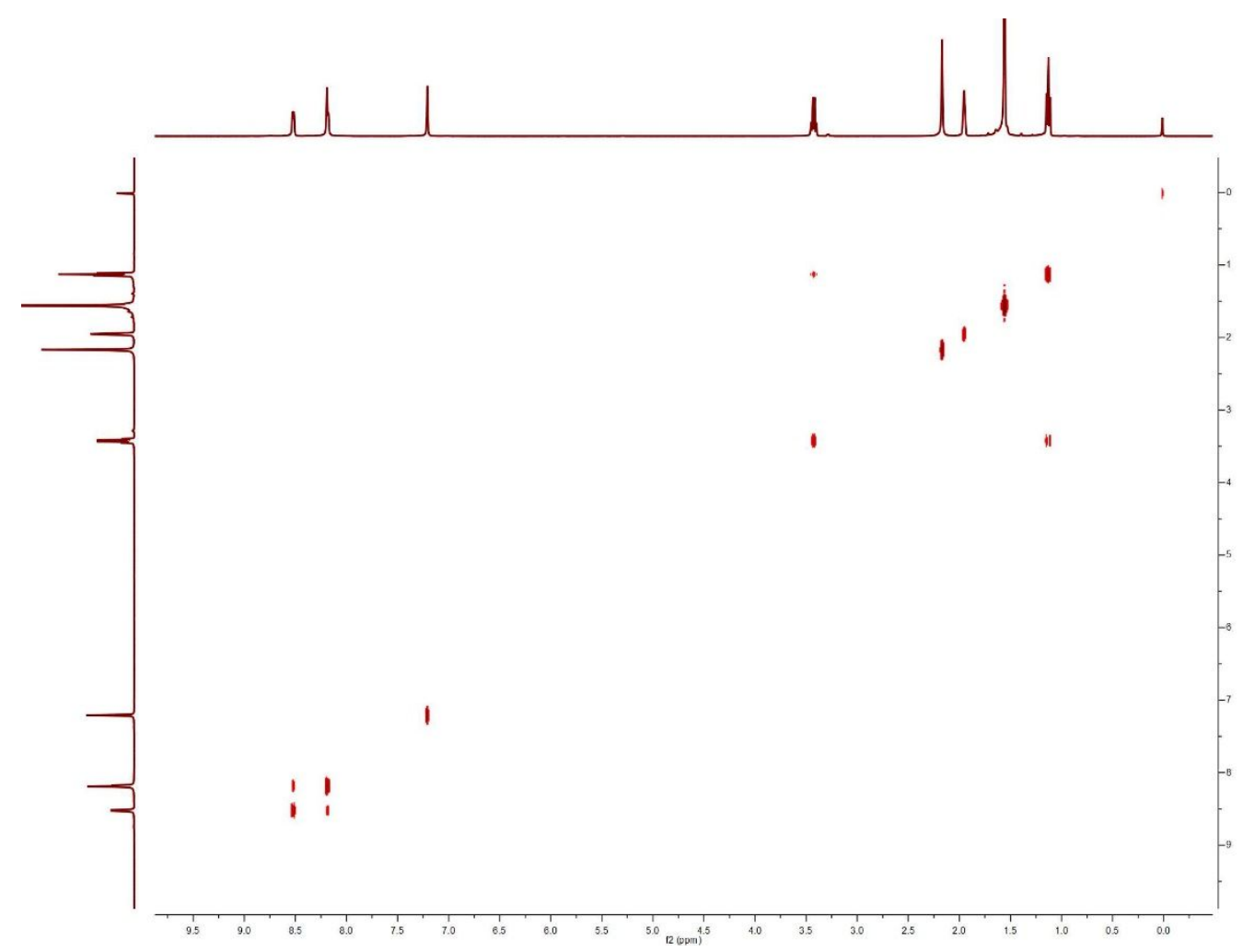

Figure S11. ${ }^{1} \mathrm{H}-{ }^{1} \mathrm{H}$ COSY NMR (400 MHz, $\mathrm{CD}_{3} \mathrm{CN}$, ppm) for 4. 


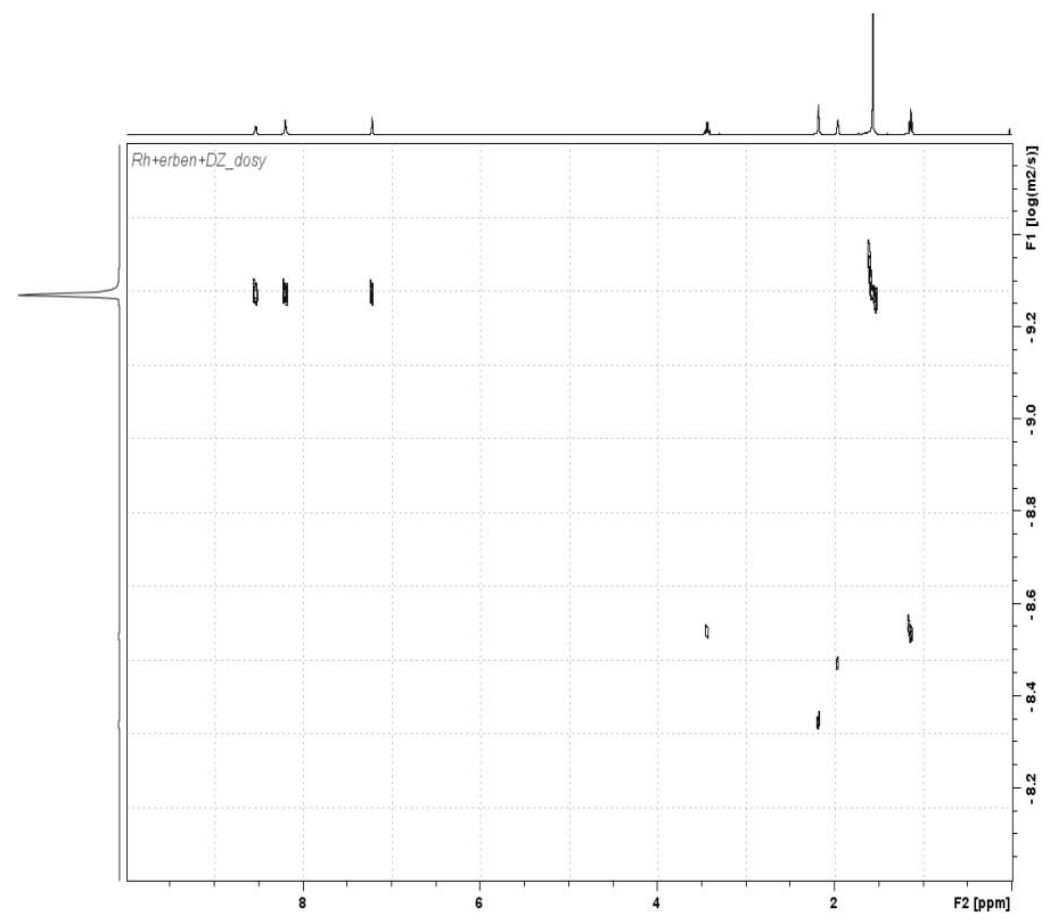

Figure S12. ${ }^{1} \mathrm{H}$ DOSY NMR (400 MHz, $\mathrm{CD}_{3} \mathrm{CN}$, ppm) for 4.

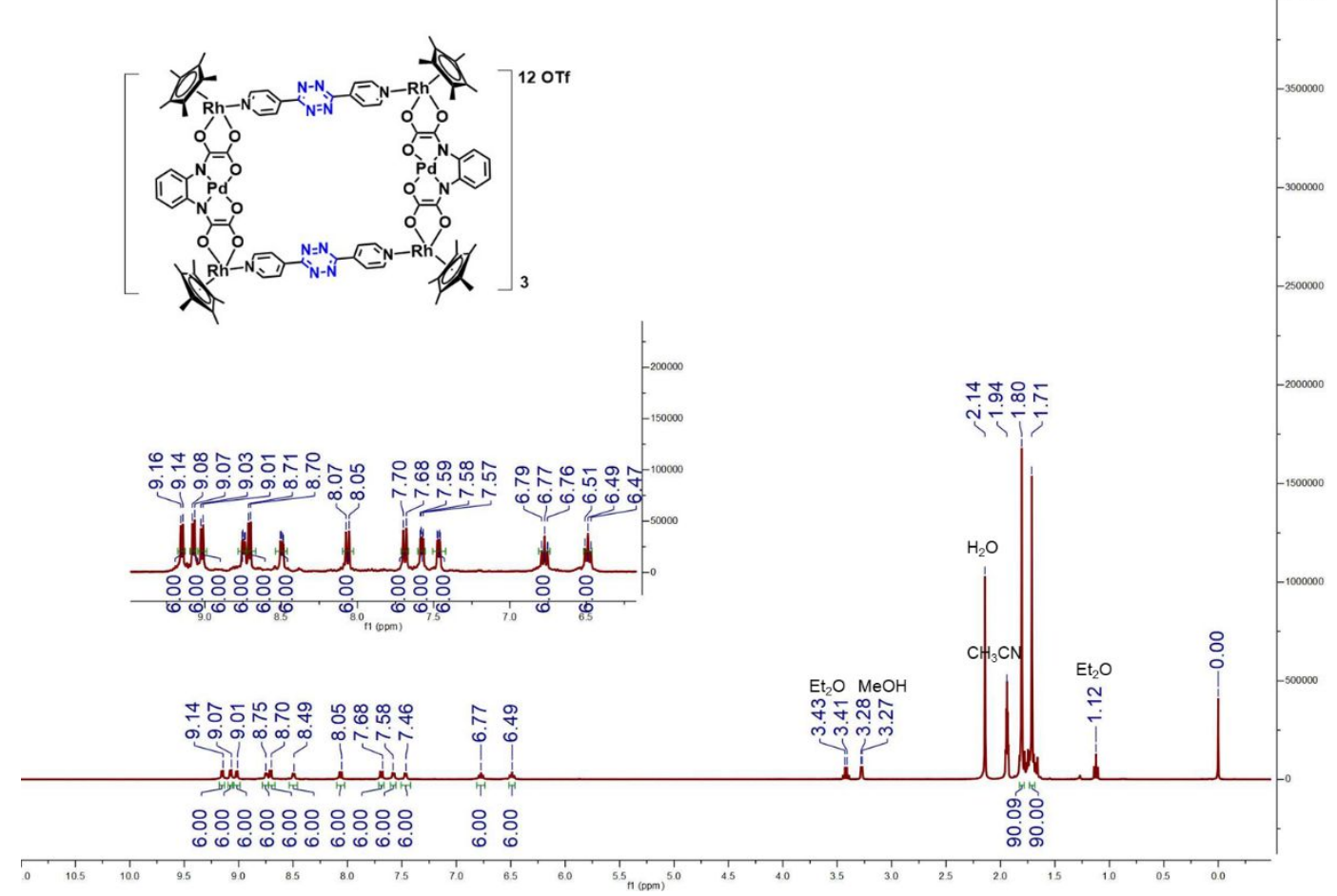

Figure S13. ${ }^{1} \mathrm{H}$ NMR (400 MHz, $\mathrm{CD}_{3} \mathrm{CN}$, ppm) for $5(10 \mathrm{mM})$. 


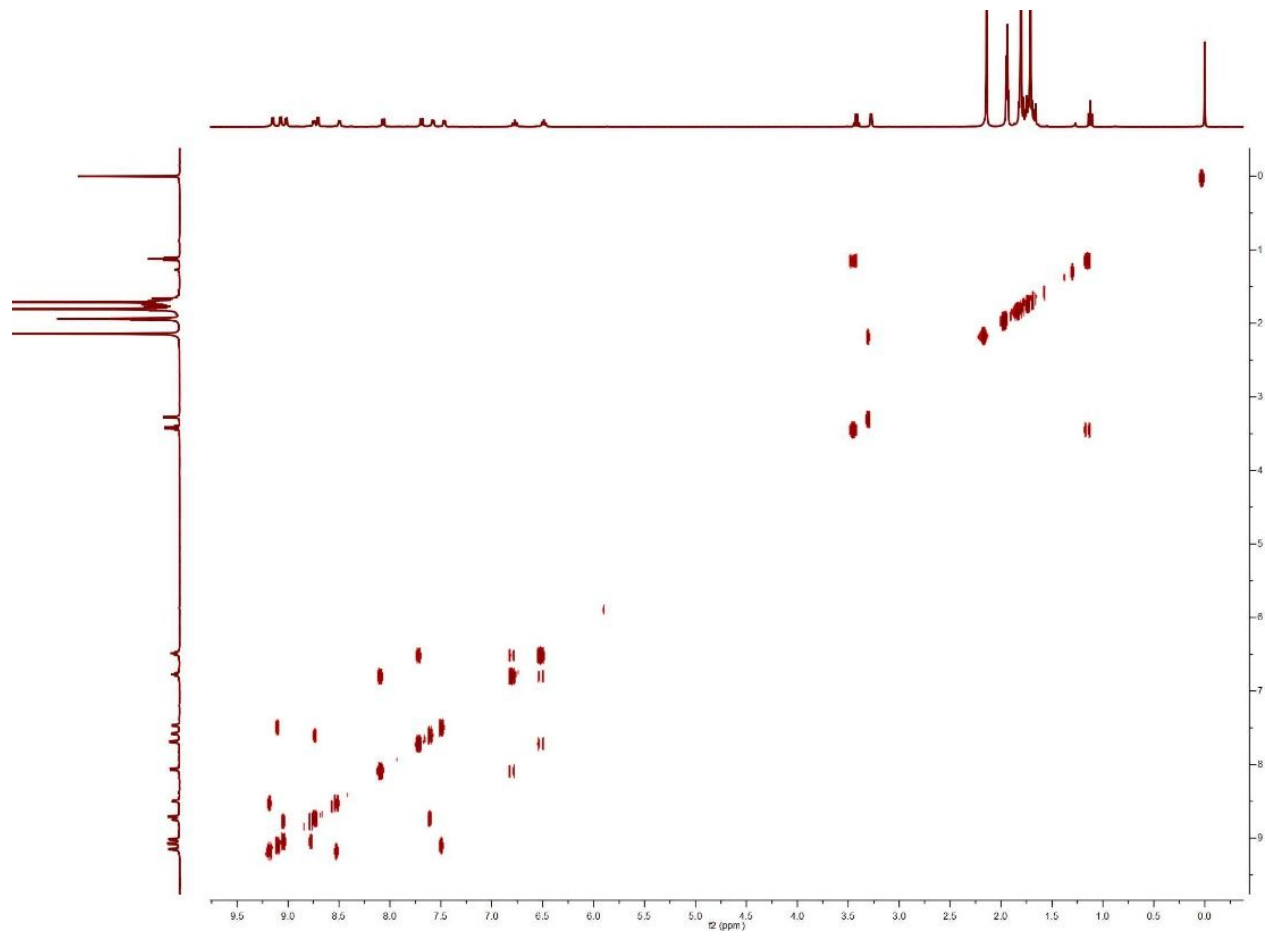

Figure S14. ${ }^{1} \mathrm{H}-{ }^{1} \mathrm{H}$ COSY NMR (400 MHz, $\mathrm{CD}_{3} \mathrm{CN}$, ppm) for $5(10 \mathrm{mM})$.

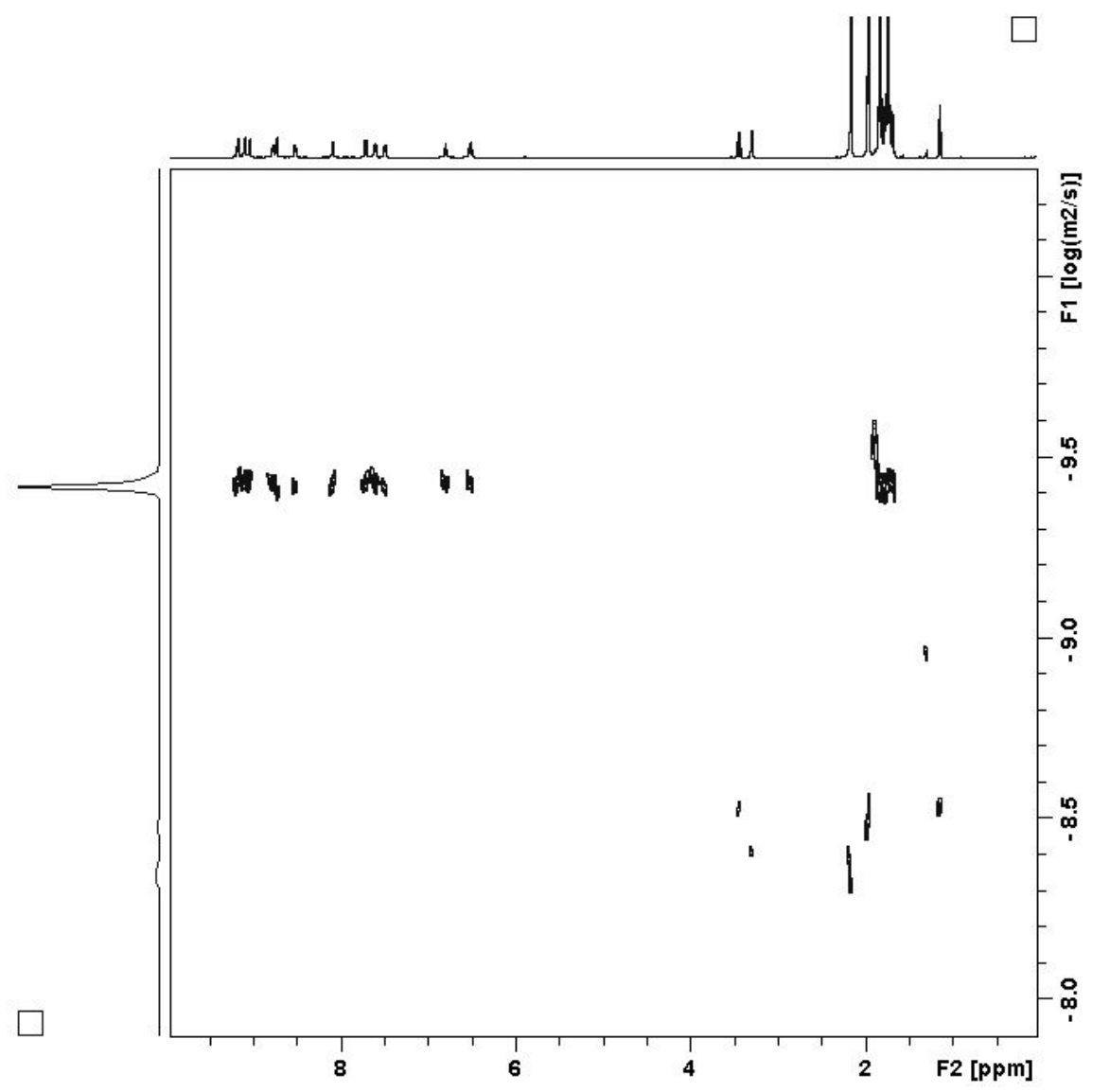

Figure S15. ${ }^{1} \mathrm{H}$ DOSY NMR (400 MHz, $\mathrm{CD}_{3} \mathrm{CN}$, ppm) for $5(10 \mathrm{mM})$. 

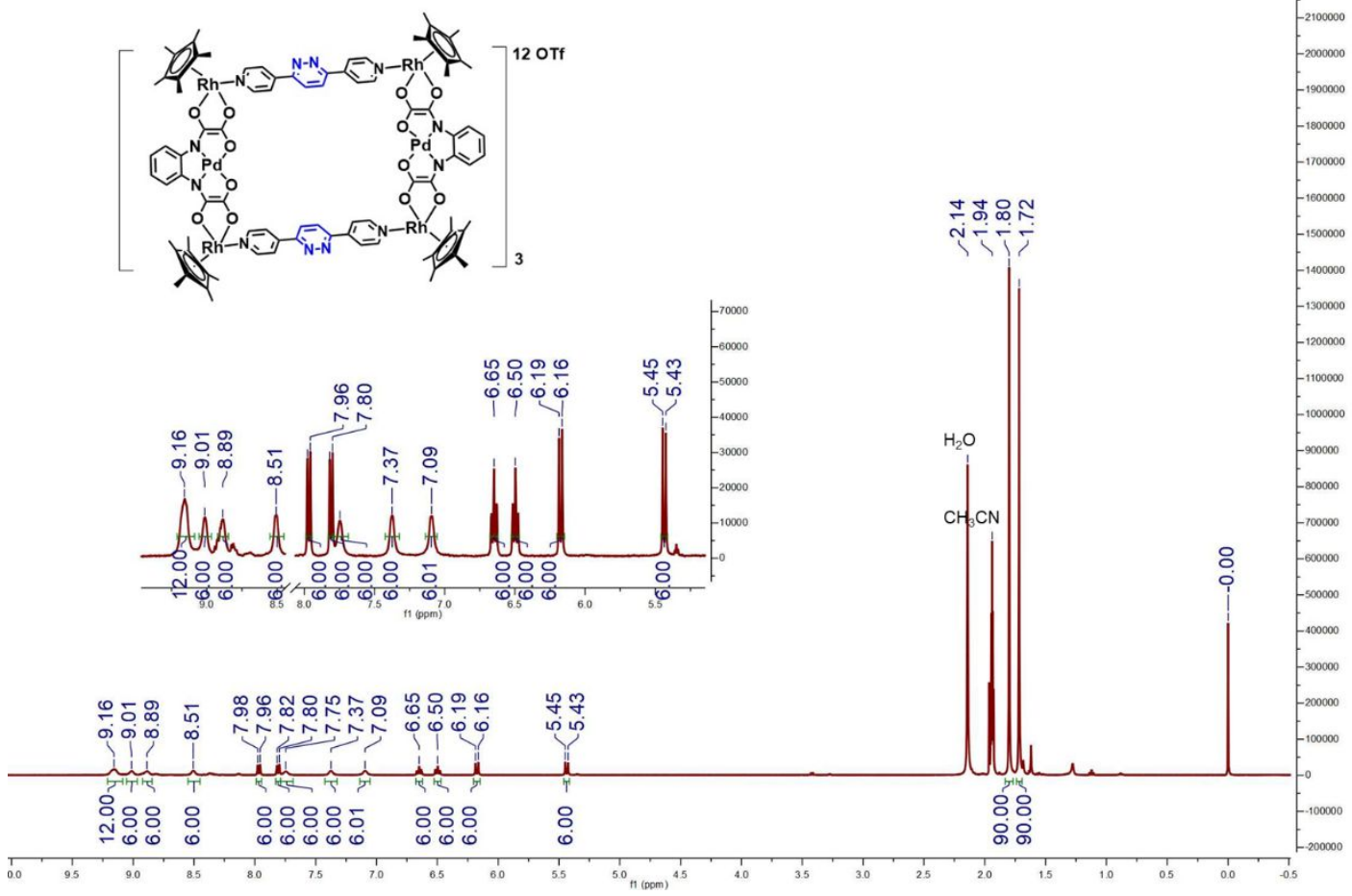

Figure S16. ${ }^{1} \mathrm{H}$ NMR $\left(400 \mathrm{MHz}, \mathrm{CD}_{3} \mathrm{CN}\right.$, ppm) for $6(5 \mathrm{mM})$.

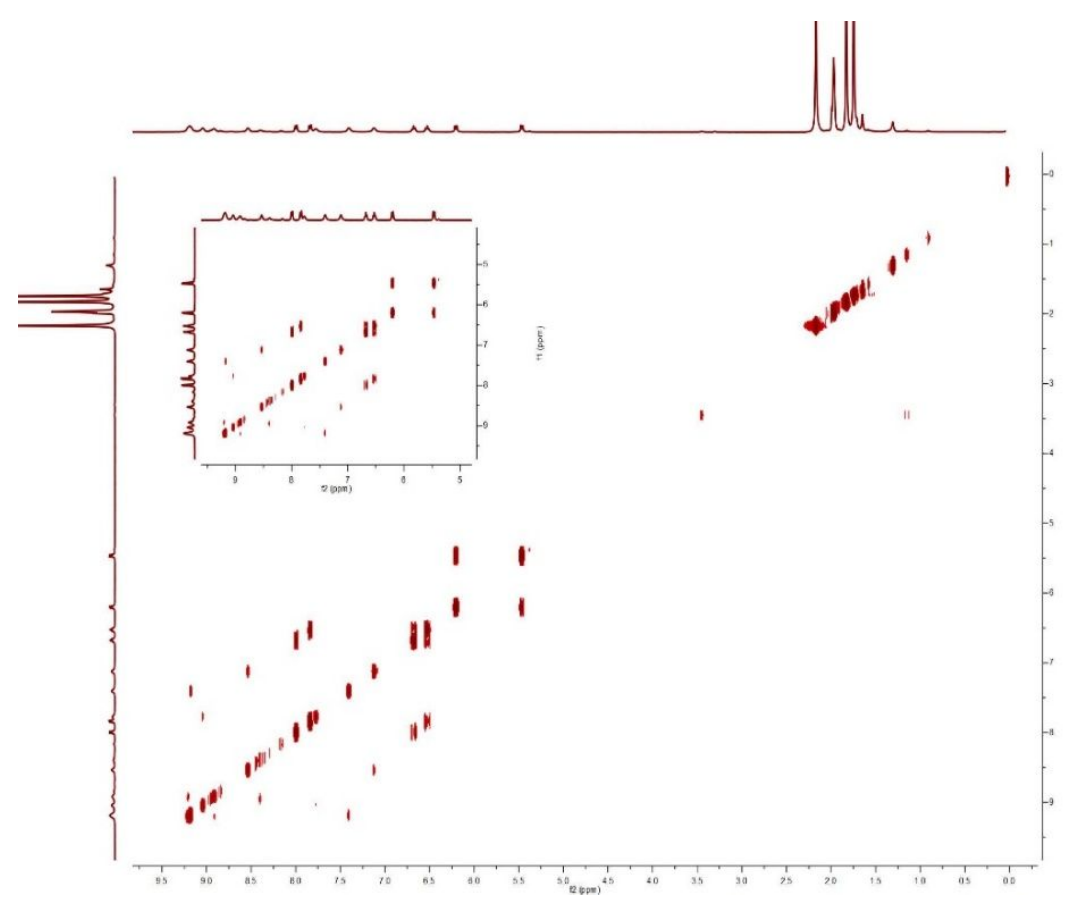

Figure S17. ${ }^{1} \mathrm{H}-{ }^{1} \mathrm{H}$ COSY NMR (400 MHz, $\mathrm{CD}_{3} \mathrm{CN}$, ppm) for $6(5 \mathrm{mM})$. 


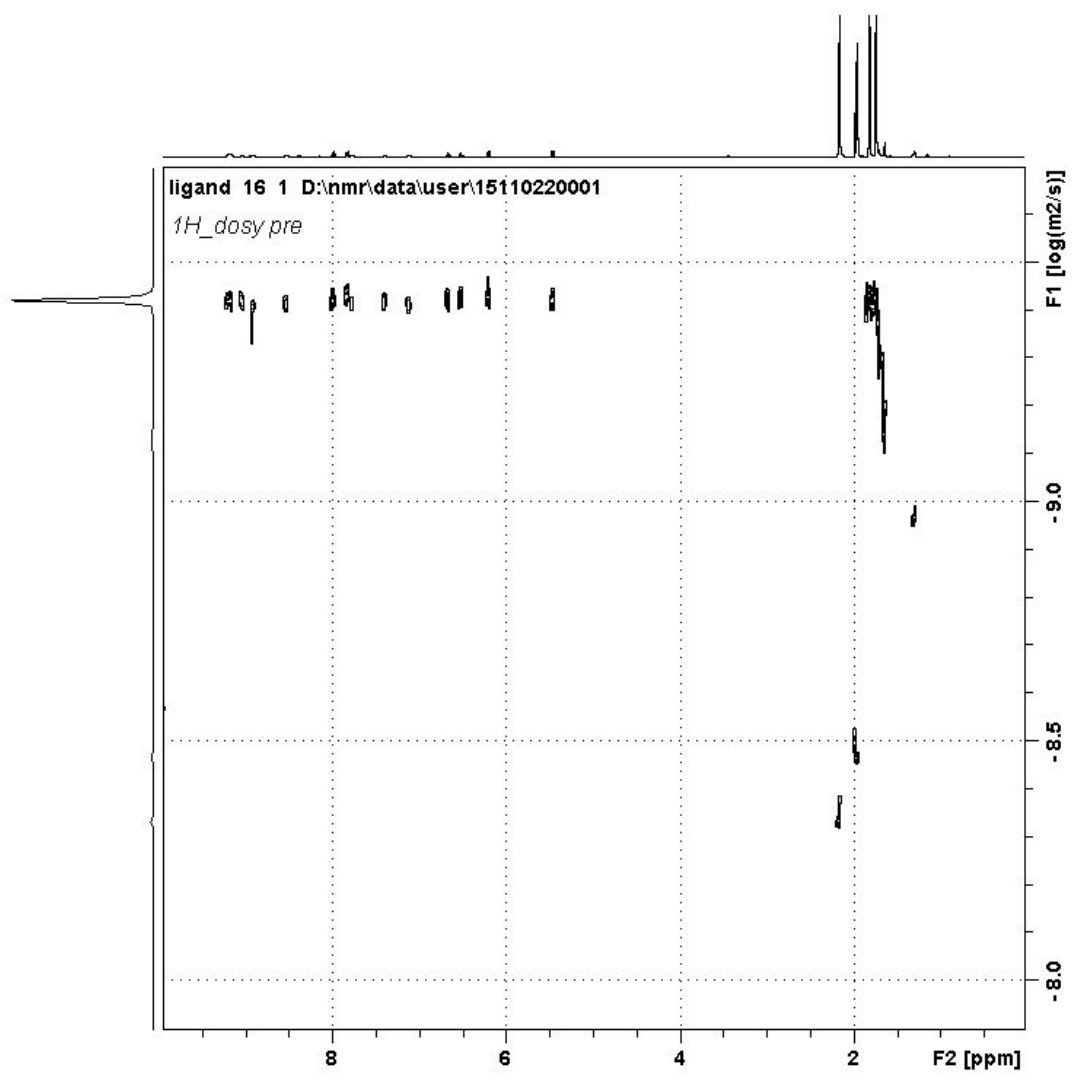

Figure S18. ${ }^{1} \mathrm{H}$ DOSY NMR (400 MHz, $\mathrm{CD}_{3} \mathrm{CN}$, ppm) for 6 (5 mM).

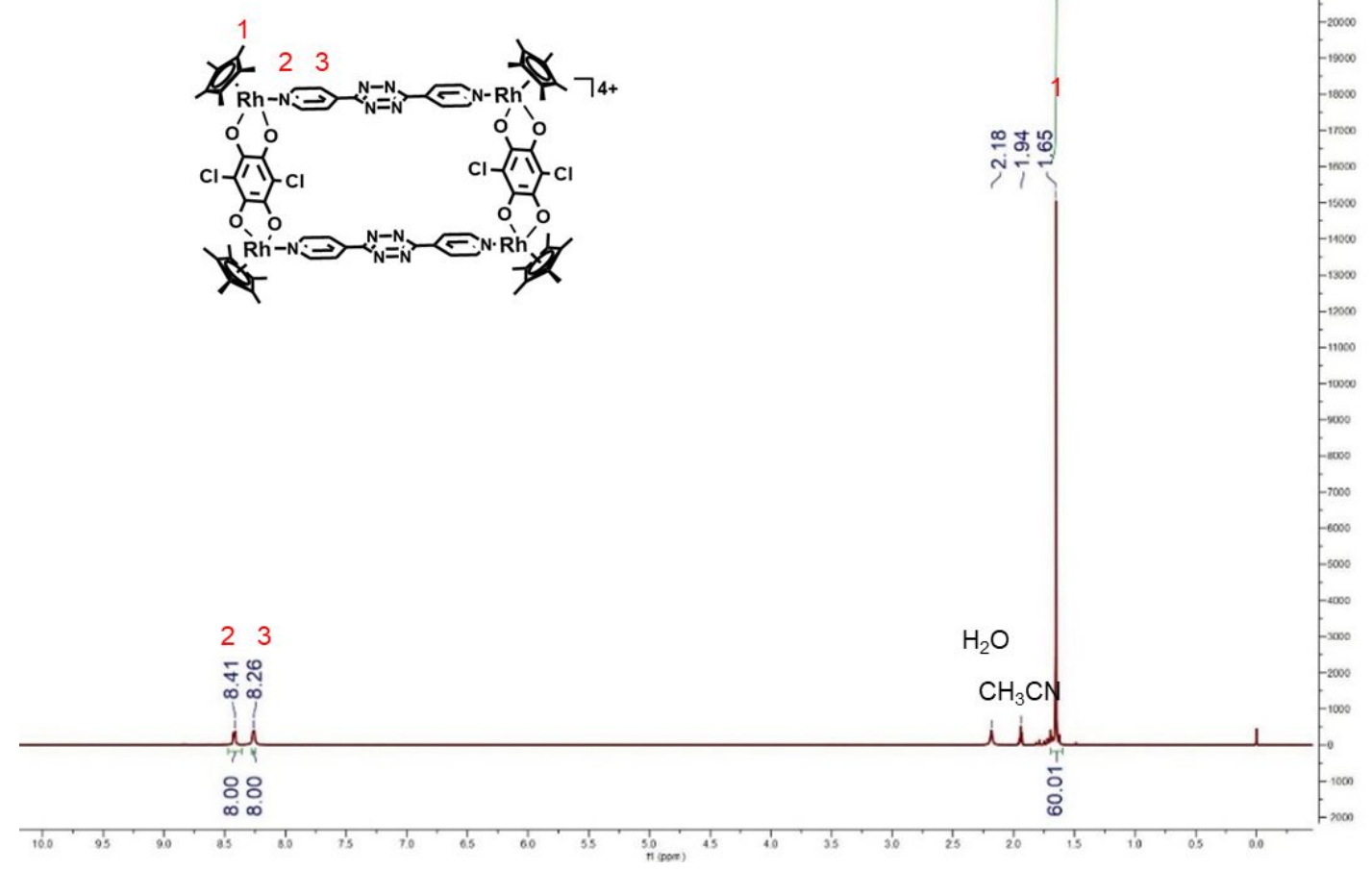

Figure S19. ${ }^{1} \mathrm{H}$ NMR (400 MHz, $\mathrm{CD}_{3} \mathrm{CN}$, ppm) for 7. 


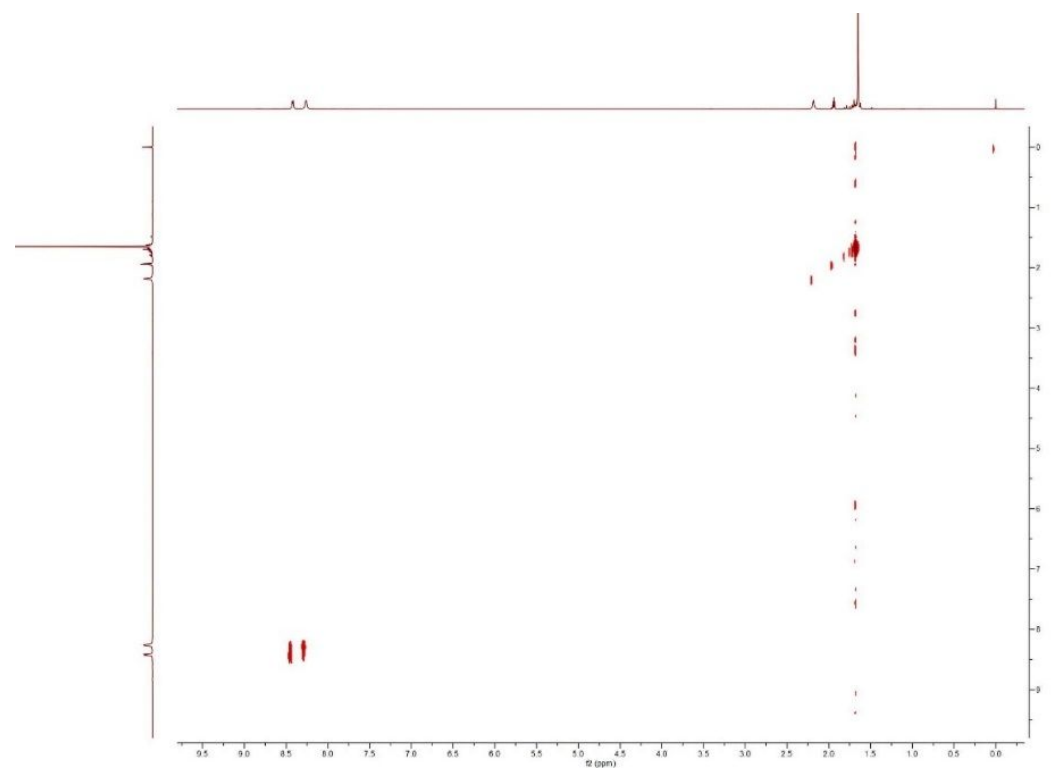

Figure S20. ${ }^{1} \mathrm{H}-{ }^{1} \mathrm{H}$ COSY NMR (400 MHz, $\mathrm{CD}_{3} \mathrm{CN}$, ppm) for 7.

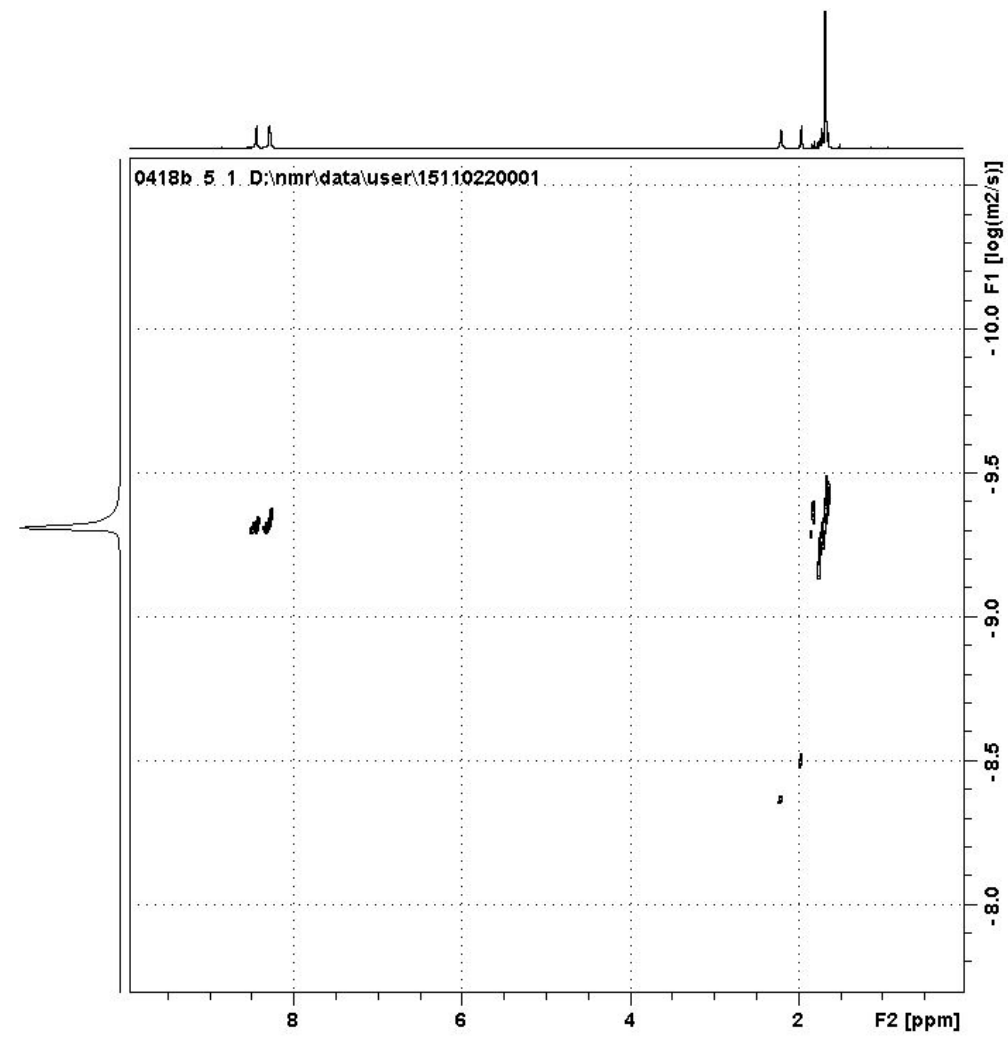

Figure S21. ${ }^{1} \mathrm{H}$ DOSY NMR (400 MHz, $\mathrm{CD}_{3} \mathrm{CN}$, ppm) for $\mathbf{7}$. 

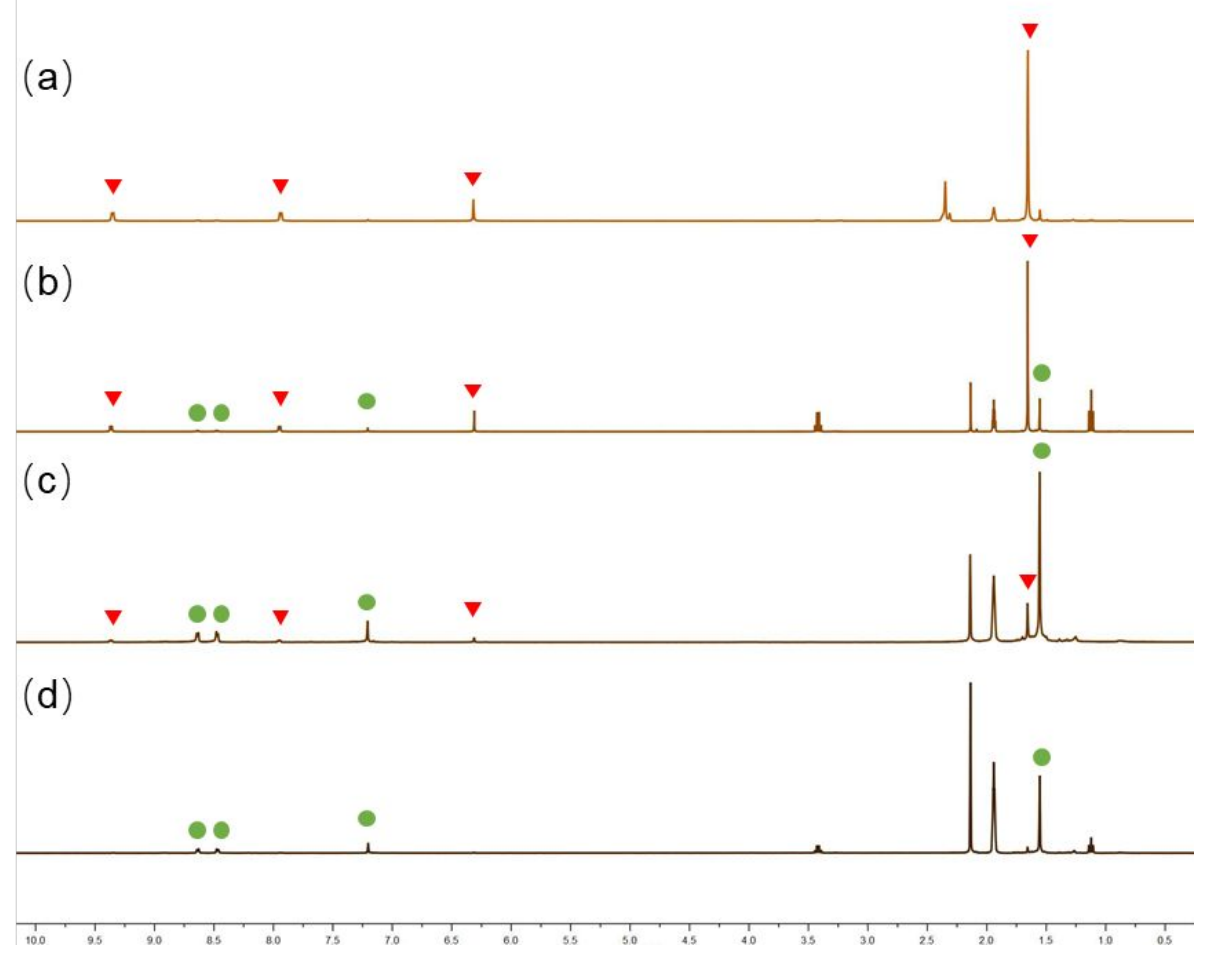

Figure S22. ${ }^{1} \mathrm{H}$ NMR (298K, $400 \mathrm{MHz}, \mathrm{CD}_{3} \mathrm{CN}$, ppm) for 3 at (a) $10 \mathrm{mM}$, (b) $5 \mathrm{mM}$, (c) $2 \mathrm{mM}$, (d) $0.5 \mathrm{mM}$. Green circles denote monomeric rings' signals; red triangles denote BRs' signals.
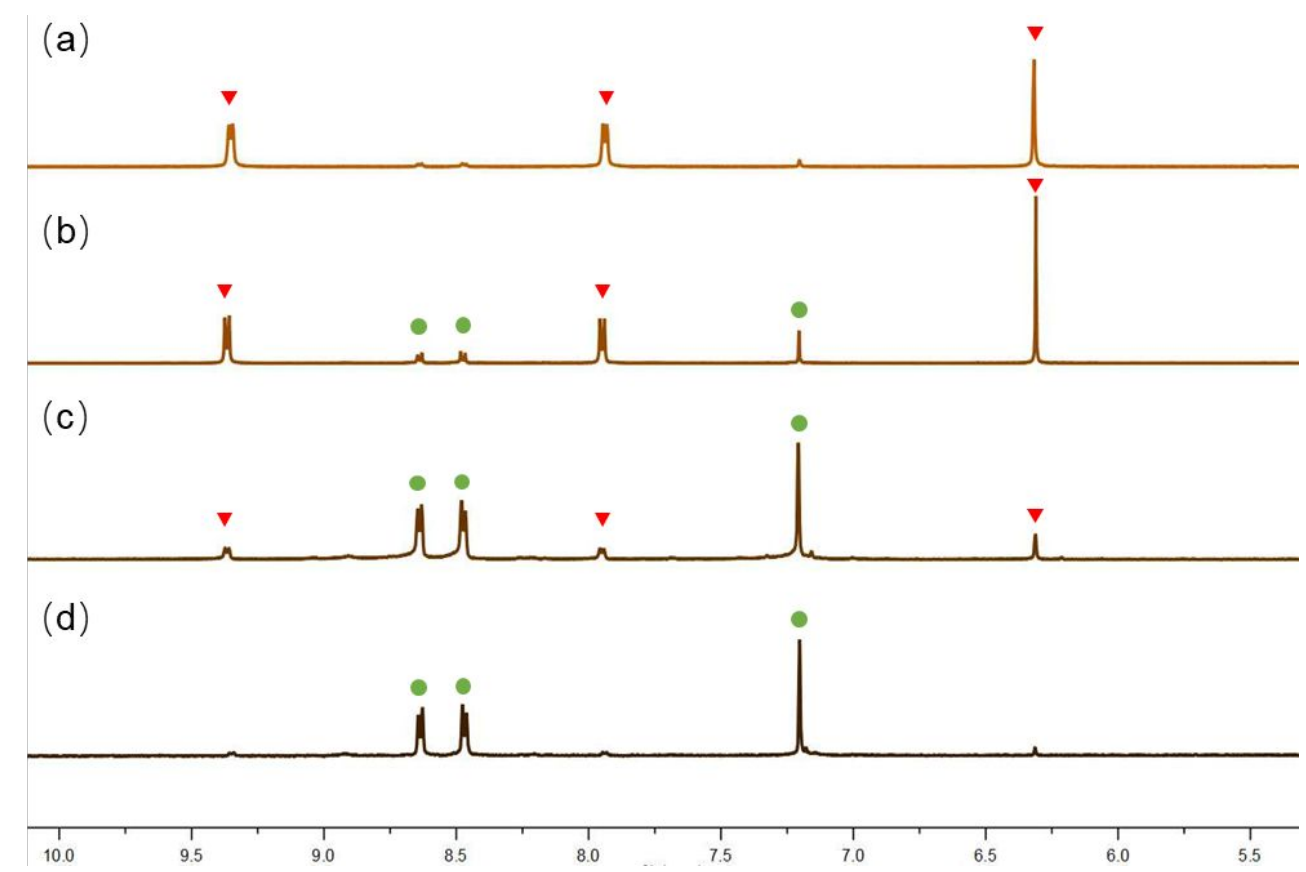

Figure S23. Partial ${ }^{1} \mathrm{H}$ NMR (298K, $400 \mathrm{MHz}, \mathrm{CD}_{3} \mathrm{CN}$, ppm) for 3 at (a) $10 \mathrm{mM}$, (b) $5 \mathrm{mM}$, (c) $2 \mathrm{mM}$, (d) $0.5 \mathrm{mM}$. Green circles denote monomeric rings' signals; red triangles denote BRs' signals. 


\section{ESI-MS spectra.}

Experimental:

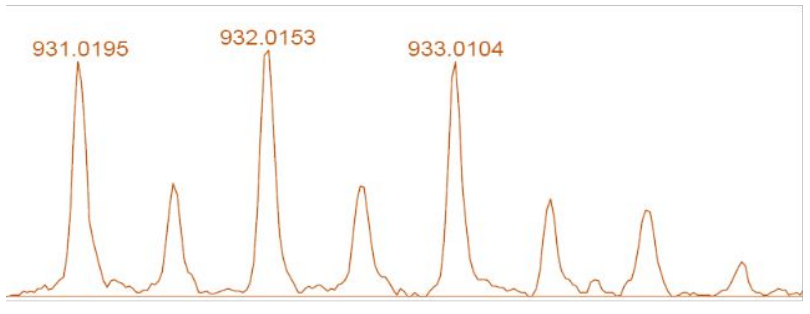

Calculated

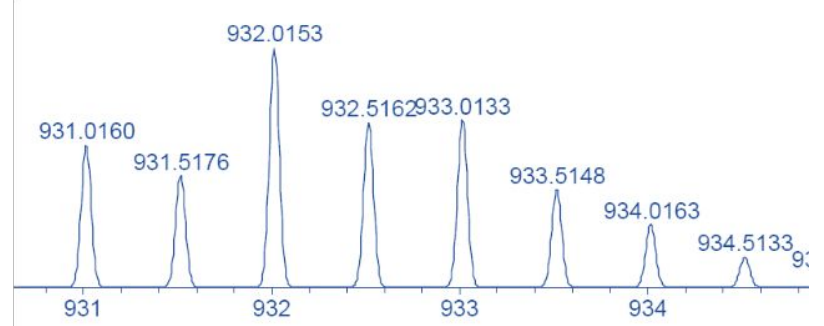

Figure S24. Calculated (top) and experimental (bottom) ESI-MS spectra of [1-2OTf] $]^{2+}$.

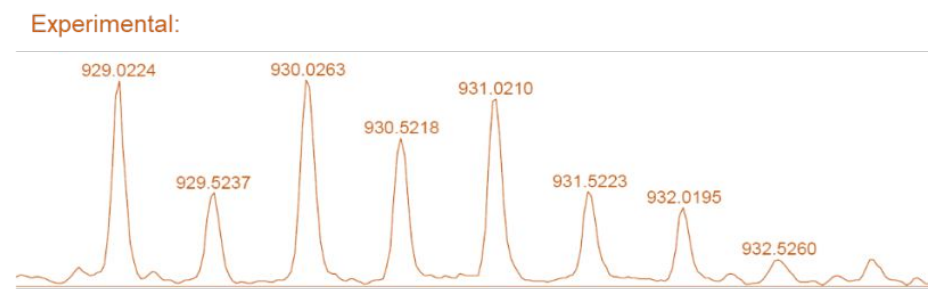

Calculated:

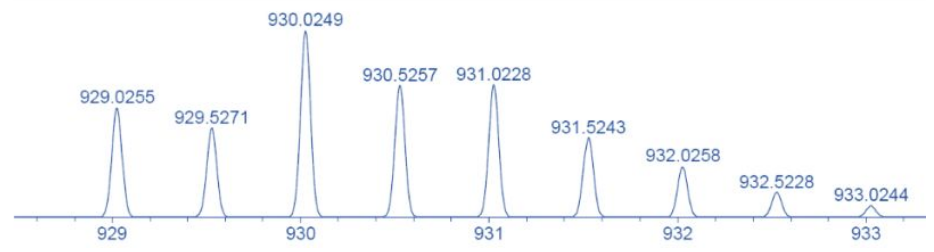

Figure S25. Calculated (top) and experimental (bottom) ESI-MS spectra of [2-2OTf $]^{2+}$. 

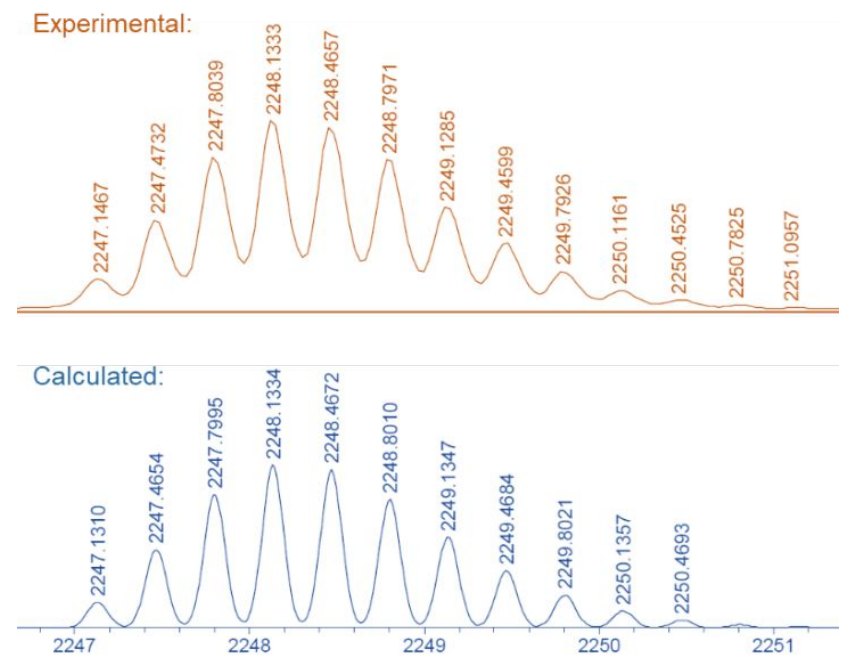

Figure S26. Calculated (top) and experimental (bottom) ESI-MS spectra of [(3-BR)-3OTf $]^{3+}$.

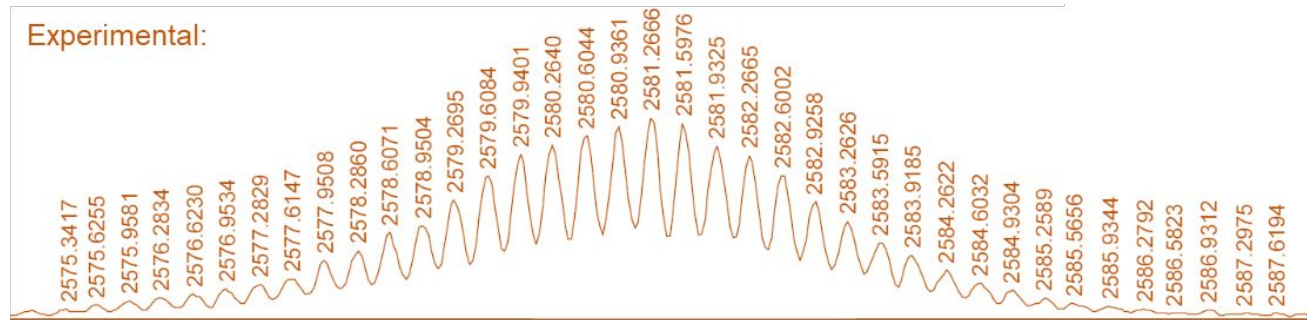

Calculated:

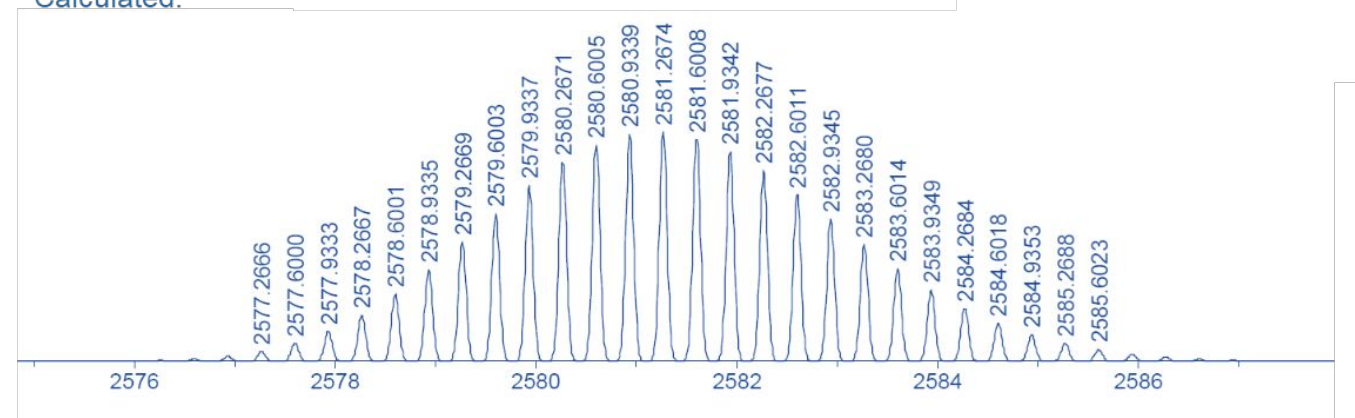

Figure S27. Calculated (top) and experimental (bottom) ESI-MS spectra of [5-3OTf] ${ }^{3+}$. 
Experimental:

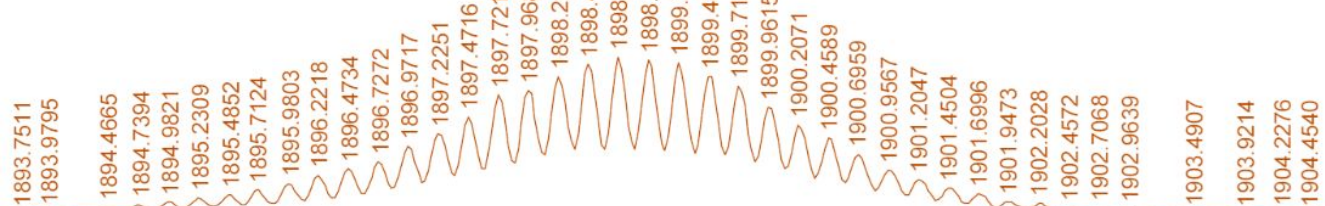

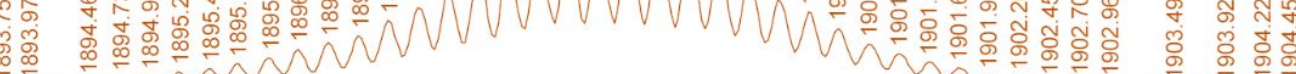

Calculated:

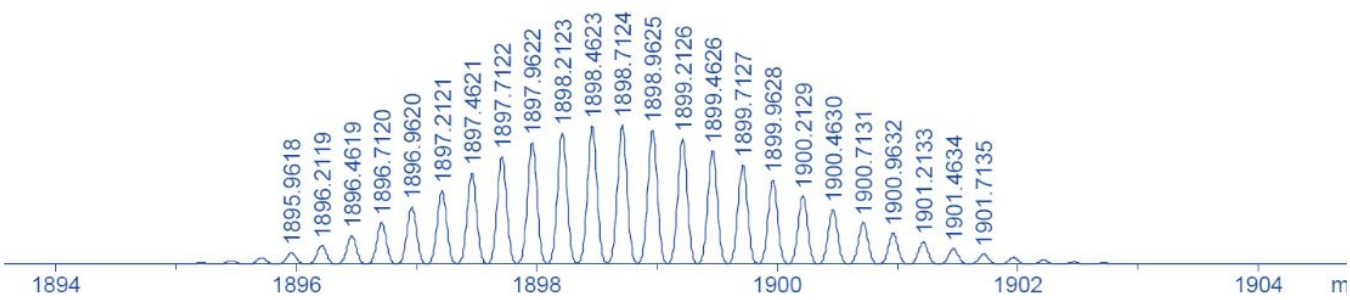

Figure S28. Calculated (top) and experimental (bottom) ESI-MS spectra of [5-4OTf $]^{4+}$.

Experimental:

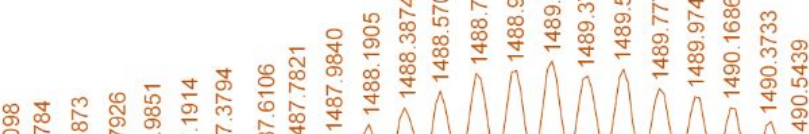

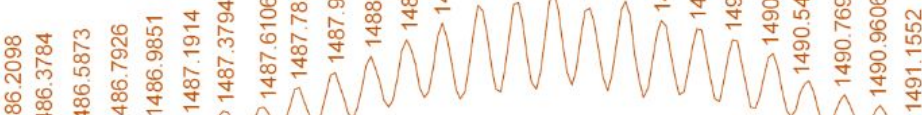

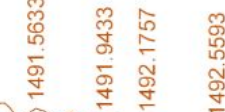

Calculated:

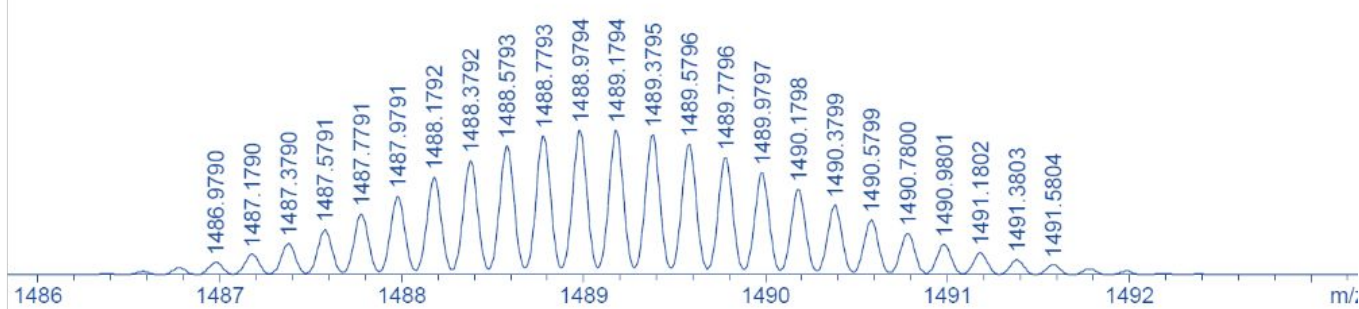

Figure S29. Calculated (top) and experimental (bottom) ESI-MS spectra of [5-5OTf $]^{5+}$. 
Calculated:

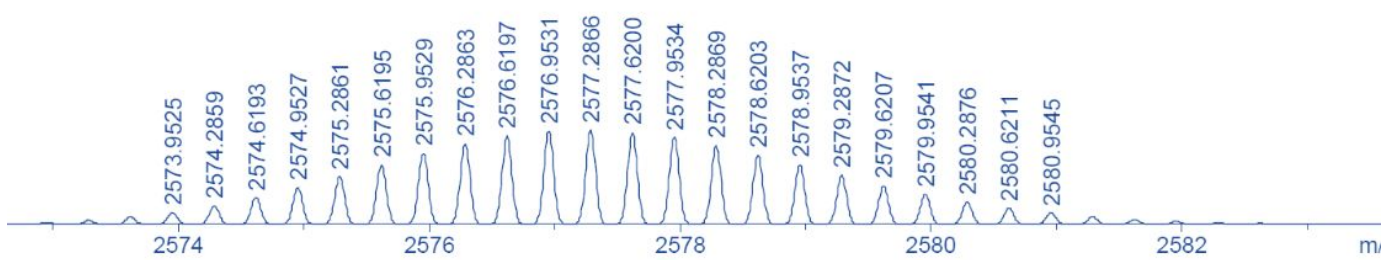

Figure S30. Calculated (top) and experimental (bottom) ESI-MS spectra of [6-3OTf $]^{3+}$.

Experimental:

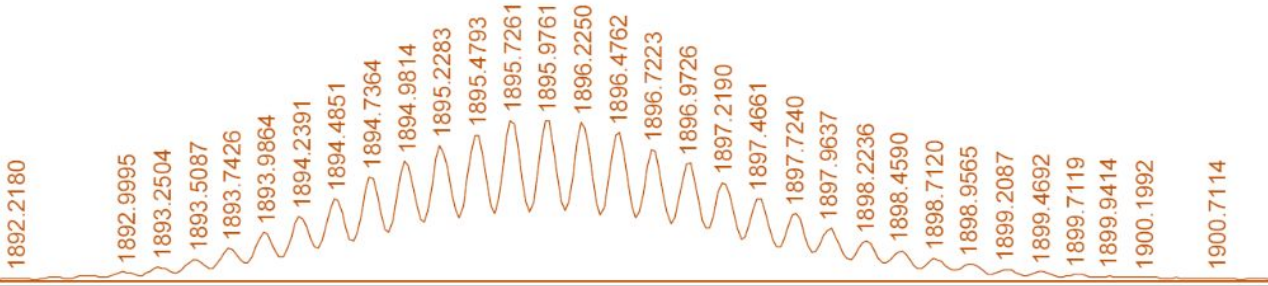

Calculated:

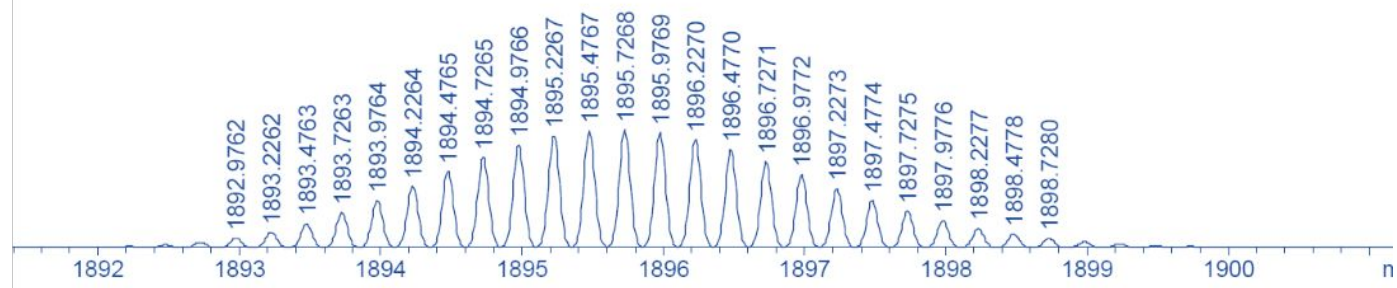

Figure S31. Calculated (top) and experimental (bottom) ESI-MS spectra of [6-4OTf] ${ }^{4+}$. 


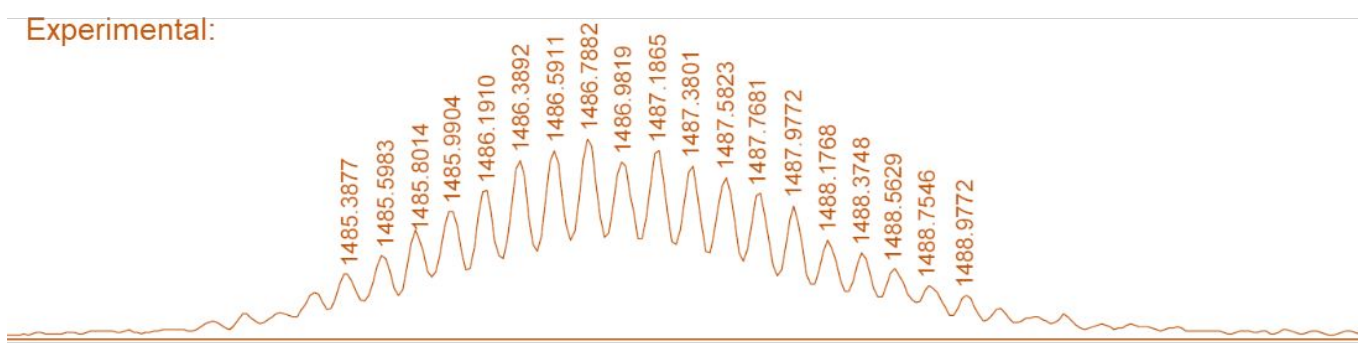

Calculated:

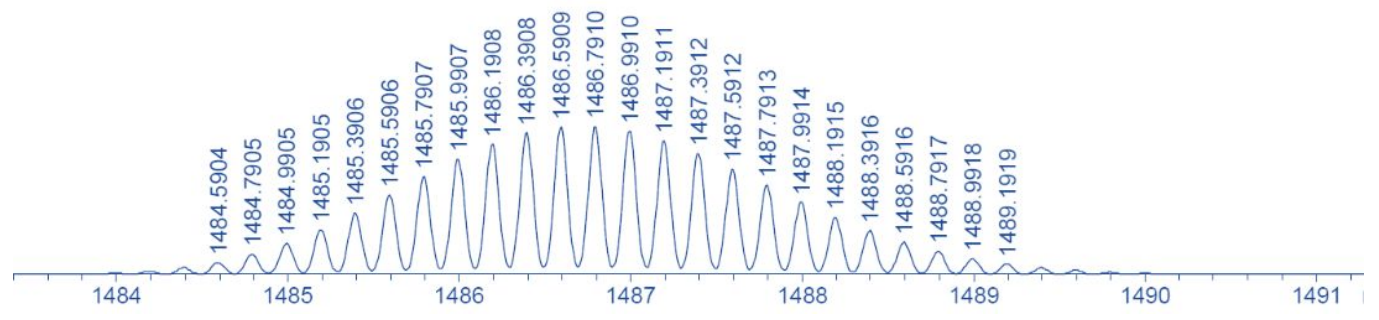

Figure S32. Calculated (top) and experimental (bottom) ESI-MS spectra of [6-5OTf $]^{5+}$. 


\section{IEDDA reaction between tetrazine fragments and dienophiles.}

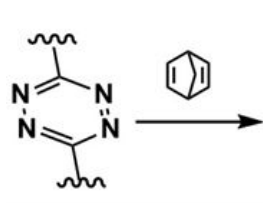

I

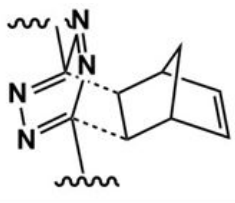

II

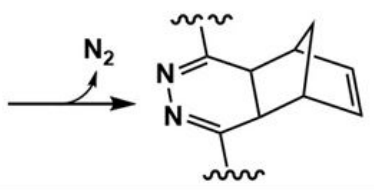

III

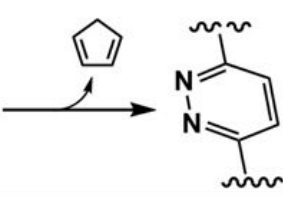

IV

Scheme S1. IEDDA reaction ${ }^{[\mathrm{S} 4][\mathrm{S} 5]}$.

Tetrazines (Scheme S1, I) and suitable dienophiles (NBD, Norbornadiene) react in an inverse electron demand hetero-Diels-Alder (ihDA)-retro-Diels-Alder (rDA) reaction cascade to form dihydropyridazines which might be further oxidised to the corresponding pyridazines $\mathbf{I V}$.

The first step in this sequence is a Diels-Alder [4+2] cycloaddition with inverse electron demand resulting in a highly strained bicyclic adduct II, which is then rapidly converted in a retro-DielsAlder step (upon release of nitrogen) to the III. The intermediate III spontaneously rearomatizes via a second retro-Diels-Alder reaction to expel a molecule of cyclopentadiene giving the product IV.

Although IEDDA reactions proceed through distorted transitory bicyclic intermediates (structures II and III, Scheme S1), the distortion is in a direction that is mostly perpendicular to the long-axis of the dipyridine ligand, thus preventing strain-induced disassembly of the macrocyclic assemblies. 


\section{Concentration-induced supramolecular structural transformation. \\ 5.1 The formation of Borromean rings.}

The formation of Borromean rings 3-BR is considered to be mainly caused by the (a) efficient noncovalent interaction and (b) matching dimensions:

(a) Potential sites on both long arm and short arm ligands should be required to form sufficiently strong noncovalent interactions. As described in main text, in the case of Borromean structure of 3-

BR, three rectangles are held together by donor-acceptor stacking interactions (ca. 3.4 $\AA$ ) between naphthazarin and electron-deficient tetrazine moieties as evidenced from single-crystal X-ray diffraction analysis. In addition, the $n-\pi$ interaction (ca. 3.1 $\AA$ ) between threaded tetrazine fragments and surrounding pyridine rings has also been observed as shown in Figure S33(b).
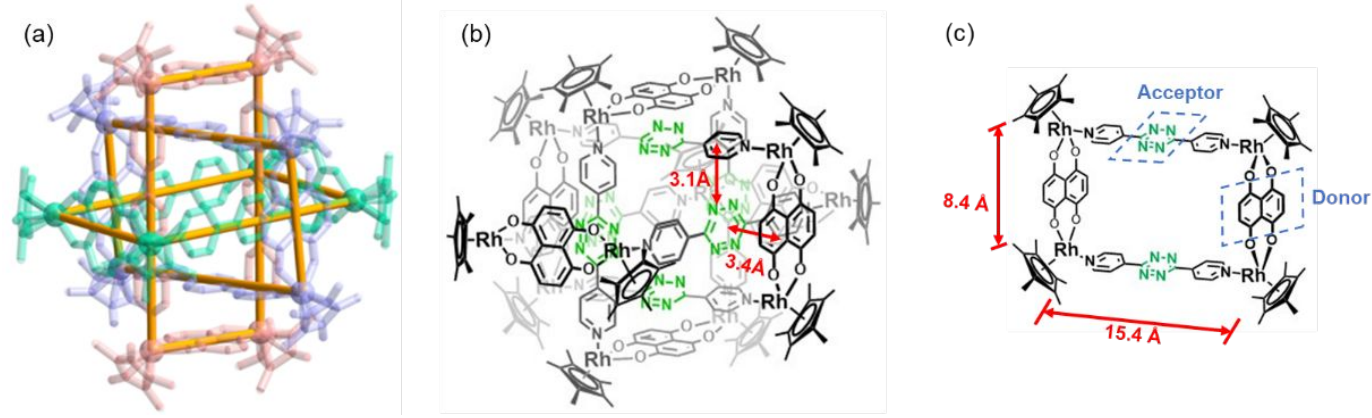

Figure S33. (a) single-crystal X-ray structure of 3-BR; (b) chemical representation and selected dimensions of 3-BR; (c) chemical representation and selected dimensions of one component ring of 3-BR

(b) The dimensions of tetrazine ligand and naphthoquinone based binuclear fragments meet the criteria to form Borromean rings. In the case of 3-BR, the length of the short-arm linker is ca. 8.4 $\AA$ as shown in Figure S33(c), which is just large enough to allow the bridging ligand with tetrazine group to pass through. In addition, the ideal long arm length (naphthoquinone-naphthoquinone parallel distance) is ca. $8.4+3.5 \AA \times 2$ (double ideal donor-acceptor stacking distance) $=$ ca. 15.4 $\AA$, which corresponds to the length of bridging ligand plus double the $\mathrm{Rh}-\mathrm{N}$ distance. Therefore, the tetrazine ligand long arm and naphthoquinone based short arm we strategically selected totally satisfies these requirements for the production of Borromean rings. 


\subsection{The kinetics survey of dilution experiment of Borromean ring 3-BR.}

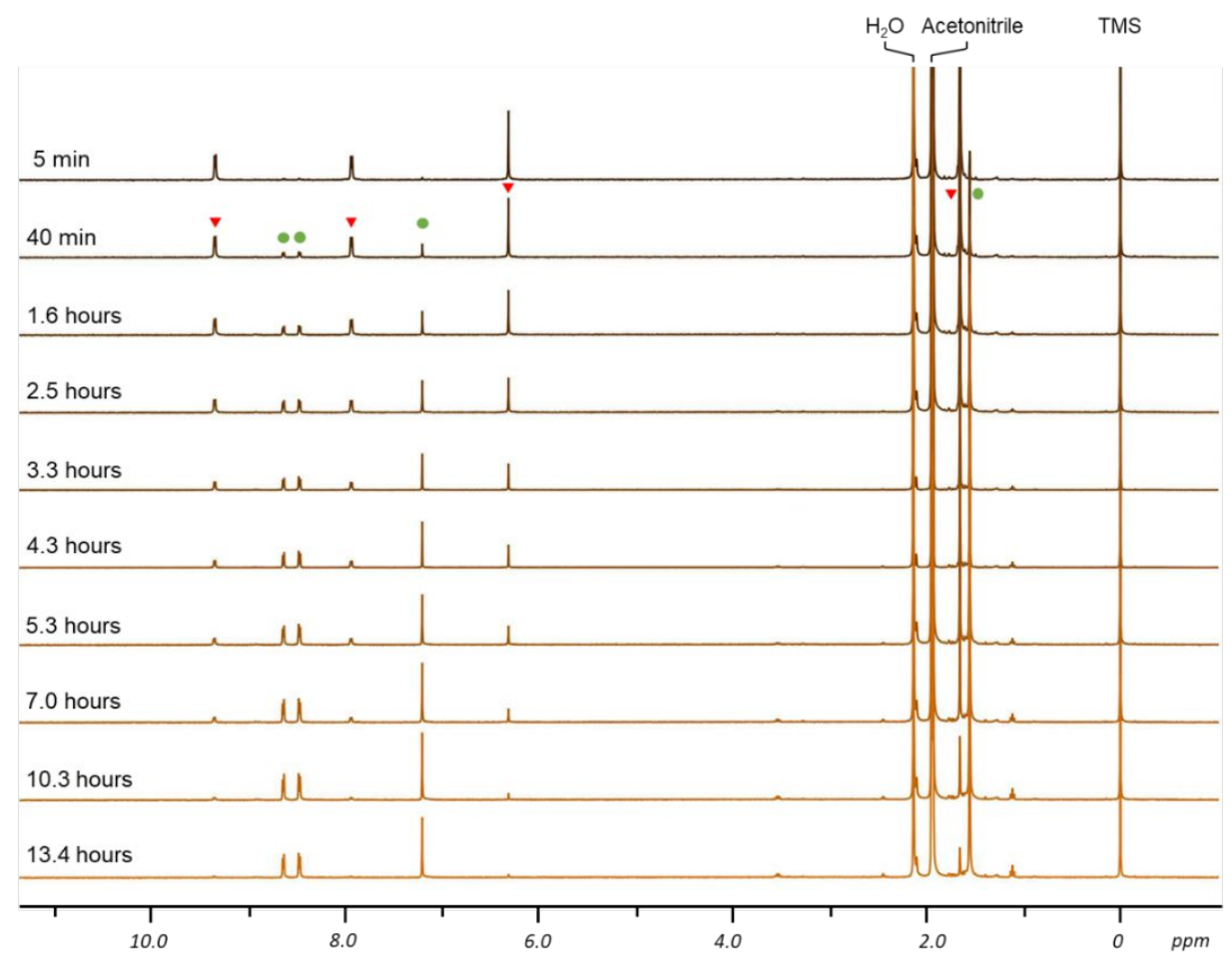

Figure S34. ${ }^{1} \mathrm{H}$ NMR (298K, $400 \mathrm{MHz}, \mathrm{CD}_{3} \mathrm{CN}$, ppm) for 3-BR diluting from high concentration $(20 \mathrm{mM}$ ) to low concentration (ca. $0.67 \mathrm{mM}$ ) has been monitored to follow the dissociation of 3BR into separate macrocycles 3-MONO. Green circles denote monomeric rings' signals; red triangles denote BRs' signals.

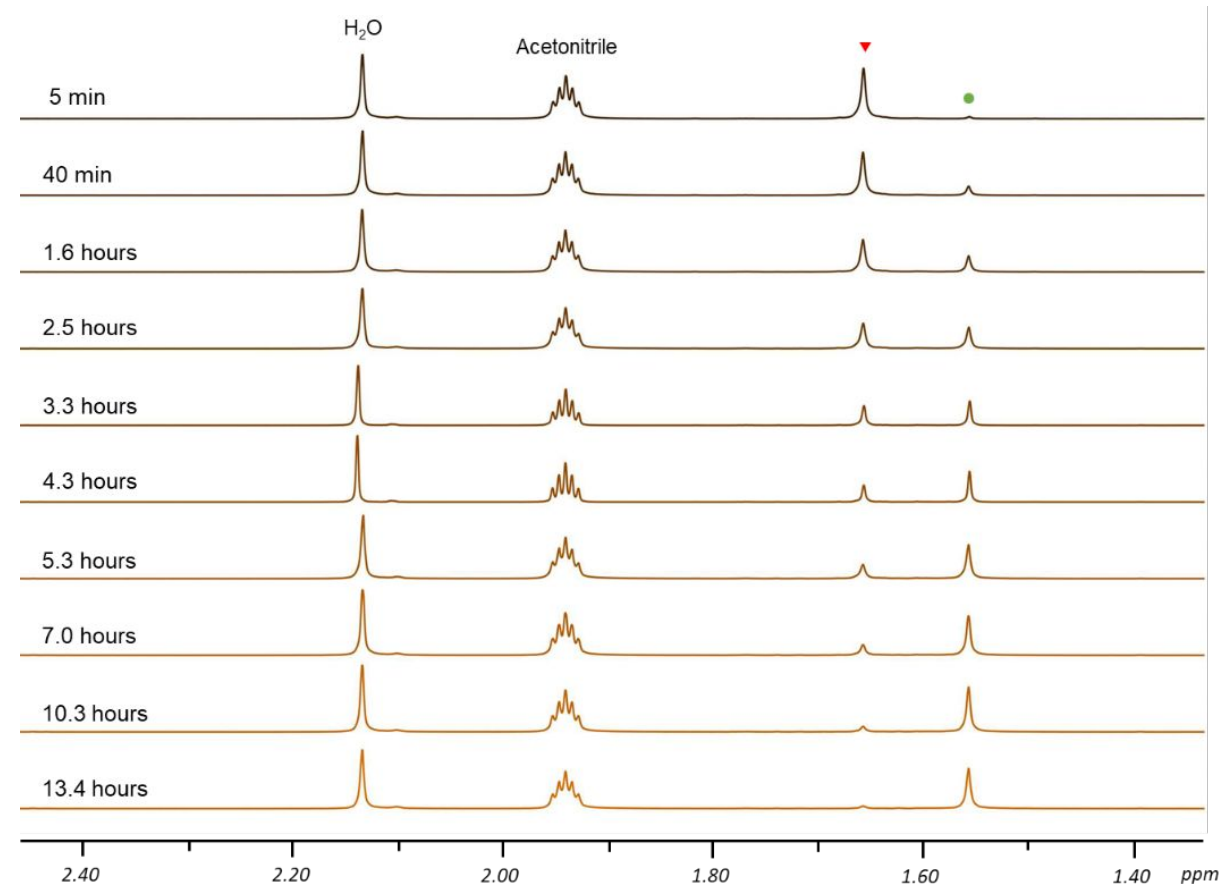

Figure S35. Aliphatic part of ${ }^{1} \mathrm{H}$ NMR (298K, $400 \mathrm{MHz}, \mathrm{CD}_{3} \mathrm{CN}$, ppm) for 3-BR diluting from high concentration $(20 \mathrm{mM})$ to low concentration (ca. $0.67 \mathrm{mM}$ ) has been monitored to follow the dissociation of 3-BR into separate macrocycles 3-MONO. Green circles denote monomeric rings' 
signals; red triangles denote BRs’ signals.

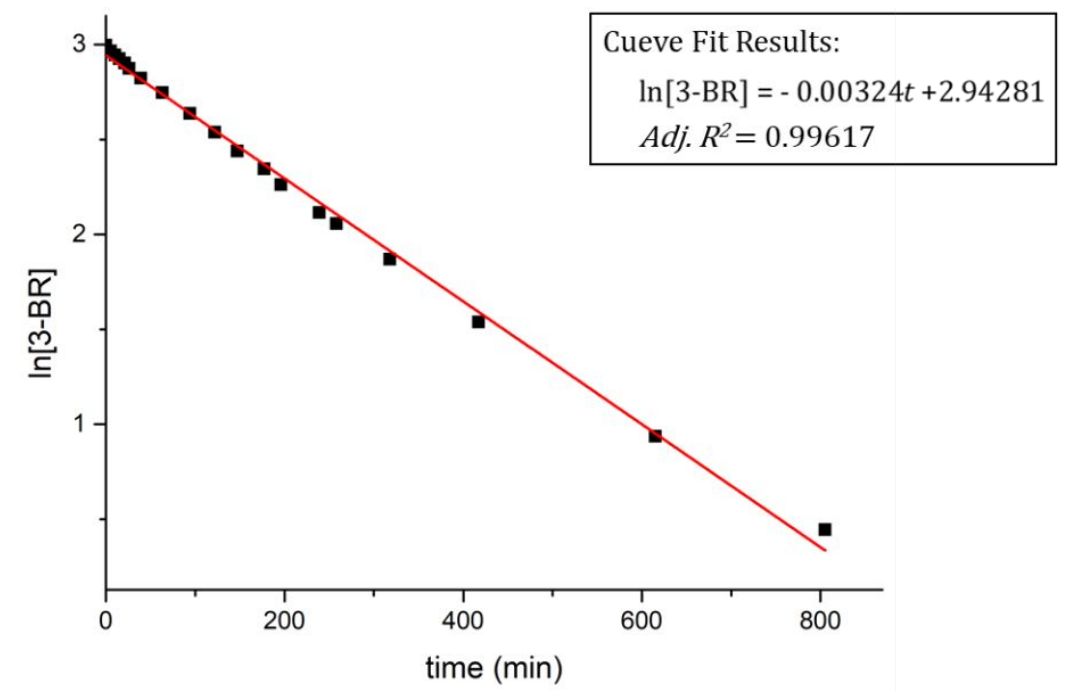

Figure S36. Plot of natural logarithm of concentration of Borromean ring $\ln ([3-B R])$ over time $t$ fitted to equation $\mathbf{I}$.

The conversion between Borromean ring 3-BR and monomeric ring 3-MONO is described by the following equation:

$$
3-\mathrm{BR} \rightleftharpoons 3(3-\mathrm{MONO})
$$

According to the rate law of first order reaction:

$$
\text { Rate }=-\frac{d[3-\mathrm{BR}]}{d t}=k[3-\mathrm{BR}]
$$

Rearrange to give:

$$
\frac{d[3-\mathrm{BR}]}{[3-\mathrm{BR}]}=-k d t
$$

Integrate both sides of the equation:

$$
\int_{[3-\mathrm{BR}]_{0}}^{[3-\mathrm{BR}]} \frac{1}{[3-\mathrm{BR}]} d[3-\mathrm{BR}]=-\int_{t_{0}}^{t} k d t
$$

Upon integration,

$$
\ln [3-\mathrm{BR}]-\ln [3-\mathrm{BR}]_{0}=-k t
$$

rearrange to solve for [3-BR] to obtain equation I:

$$
\ln [3-\mathrm{BR}]=-k t+\ln [3-\mathrm{BR}]_{0}
$$

Linear regression analysis of the experimental data (Figure S36) show that the conversion process could be well fitted by the rate law of first order reaction, which giving conversion reaction rate coefficient $k=0.00324 / \mathrm{min}$ at $298 \mathrm{~K}$ with an adjusted R-squared value of 0.99617 as shown in table S1. 
Table S1. Results of linear regression analysis of the experimental data.

\begin{tabular}{|c|c|c|}
\hline Model & \multicolumn{2}{|c|}{$\ln [3-\mathrm{BR}]=-k t+\ln [3-\mathrm{BR}]_{0}$} \\
\hline Slope $-k / \mathrm{min}^{-1}$ & Intercept $\ln [3-B R]_{0}$ & Adjusted $R^{2}$ \\
\hline-0.00324 & 2.94281 & 0.99617 \\
\hline
\end{tabular}




\section{DFT computational details.}

All density functional theory (DFT) calculations were carried out using the SIESTA package with numerical atomic orbital basis sets and Troullier-Martins norm-conserving pseudopotentials. ${ }^{[\mathrm{S} 6][\mathrm{S} 7]}$ The DFT functional utilized is the PBE functional, ${ }^{[\mathrm{S} 8]}$ a generalized gradient approximation DFT method. To account for dispersion interaction, the long-range dispersion correction ${ }^{[\mathrm{S} 9]}$ of Grimme et al. was applied to the PBE functional. A double- $\zeta$ plus polarization (DZP) basis set was employed. The orbital-confining cutoff radii were determined from an energy shift of $0.01 \mathrm{eV}$. The energy cutoff for the real space grid used to represent the density was set as $150 \mathrm{Ry}$. The molecule was placed in the center of a cubic supercell with a length of $50 \AA$ for each edge. Only $\Gamma$-point was used to sample the Brillouin zone in our calculations due to the large lattice parameter of the supercell. All atoms were relaxed until all the Cartesian forces on the atoms were lower than $0.02 \mathrm{eV} /$ Bohr.

Assuming that the vibrational contribution to the Gibbs-free energy change is cancelled forming the Borromean from the three monomers, the free-energy change for the formation of the Borromean at temperature $T$ can be estimated as equation II.

$$
\Delta G=\Delta E_{e}-T \cdot\left(\Delta S_{\mathrm{t}}+\Delta S_{\mathrm{r}}\right)
$$

where $\Delta E_{e}, \Delta S_{\mathrm{t}}$ and $\Delta S_{\mathrm{r}}$ are the potential energy change, translational entropy change, and rotational entropy change, respectively.

Table S2. Energetic results for the formation of the Borromean structure from three monomers.

\begin{tabular}{|l|c|c|c|c|c|}
\hline & $\begin{array}{c}\text { Total Energy } \\
(\mathrm{eV})\end{array}$ & $\begin{array}{c}S_{\mathrm{t}}{ }^{a} \\
(\mathrm{cal} / \mathrm{mol} / \mathrm{K})\end{array}$ & $\begin{array}{c}S_{\mathrm{r}}{ }^{b} \\
(\mathrm{cal} / \mathrm{mol} / \mathrm{K})\end{array}$ & $\begin{array}{c}\Delta E_{\mathrm{e}}{ }^{c} \\
(\mathrm{kcal} / \mathrm{mol})\end{array}$ & $\begin{array}{c}\Delta G^{d} \\
(\mathrm{kcal} / \mathrm{mol})\end{array}$ \\
\hline Monomer & -23464.56 & 71.241 & 71.200 & & \\
\hline Borromean & -70399.79 & 74.515 & 78.472 & -140.6 & -58.8 \\
\hline
\end{tabular}

$a$ Translational entropy at $298.15 \mathrm{~K}$.

${ }^{b}$ Rotational entropy at $298.15 \mathrm{~K}$.

${ }^{c}$ Potential energy change.

${ }^{d}$ Gibbs-free energy change at $298.15 \mathrm{~K}$. 


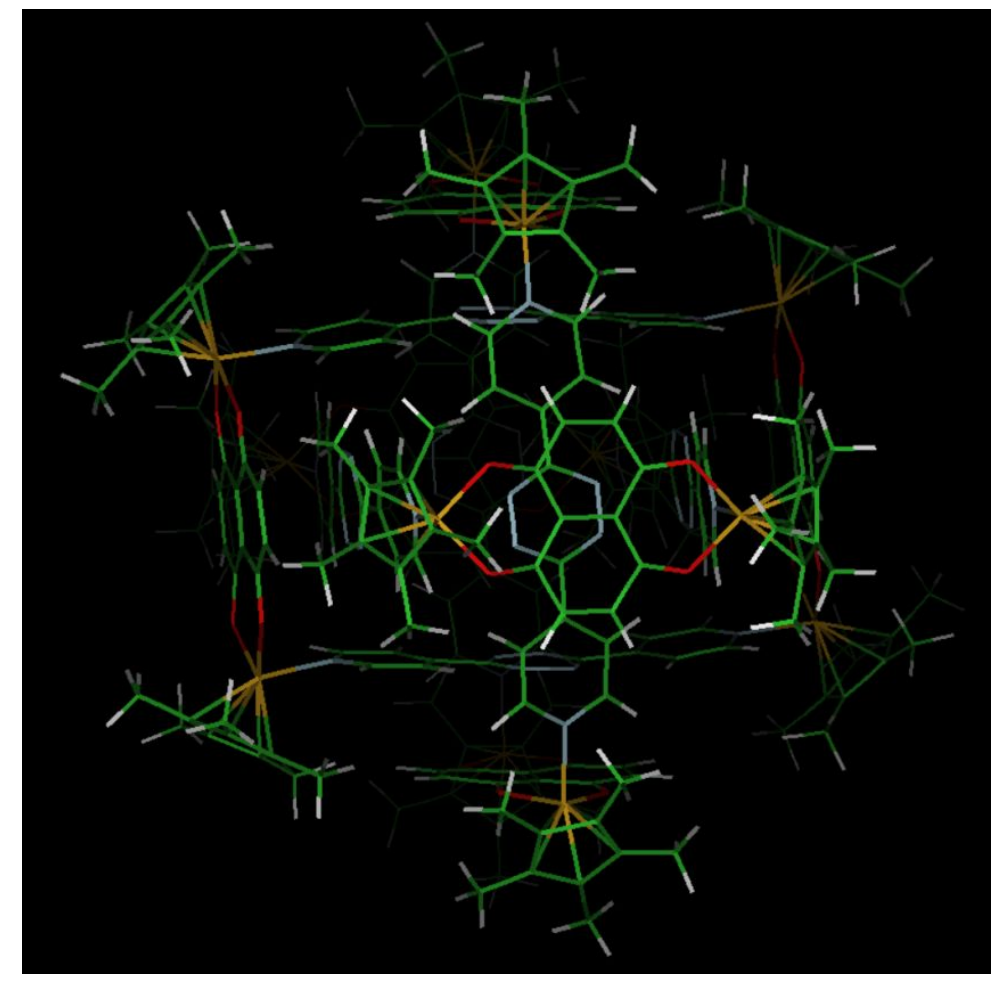

Figure S37. Geometries of the BRs structure 3-BR optimized with the PBE density functional method.

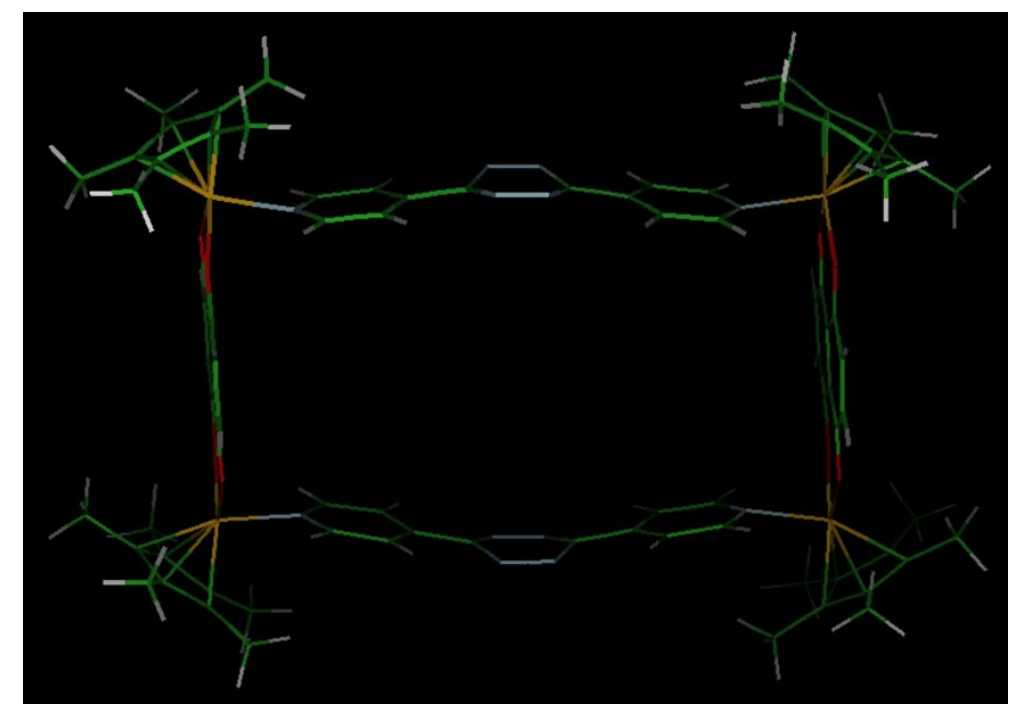

Figure S38. Geometries of the monomeric ring 3-MONO optimized with the PBE density functional method. 


\section{Single-crystal-to-single-crystal transformation experiment.}
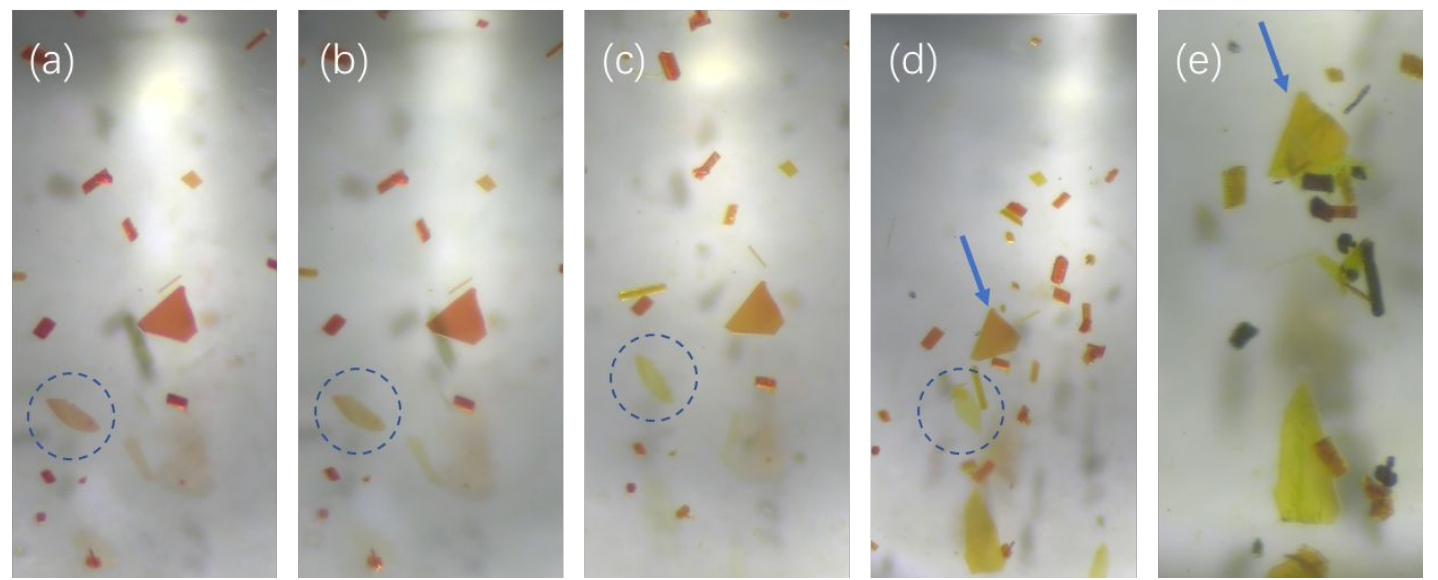

Figure S39. Photos of crystals of complex 1 reacting with excess NBD in ether. (a) 0 hours; (b) 6 hours; (c) 12 hours; (d) 24 hours; (e) 72 hours. Gradual colour changes from red to light yellow could be observed on sheet-like crystal in blue cycle, corresponding to the degradation of intensecoloured tetrazine units. 


\section{Single-crystal $X$-ray diffraction analysis.}

(a)

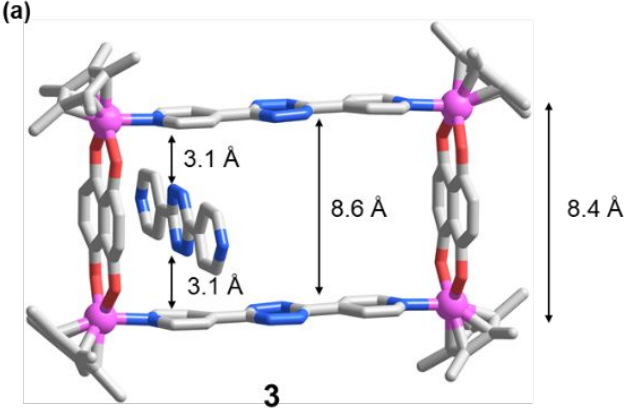

(b)

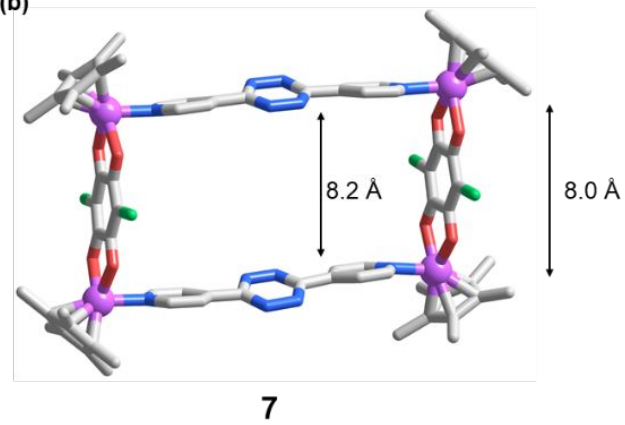

Figure S40. Partial single-crystal X-ray structure and selected dimensions of (a) one component monomer of Borromean structure $\mathbf{3}$ and a threading tetrazine ligand of another component ring; (b) solid-state structure of tetranuclear monomeric ring 7. Counteranions and hydrogen atoms are omitted for clarity (C, gray; $\mathrm{N}$, blue; $\mathrm{O}$, red; $\mathrm{Cl}$, green; $\mathrm{Rh}$, violet). 


\section{X-ray crystallography details.}

Single crystals suitable for X-ray diffraction studies were obtained by recrystallization at room temperature. X-ray intensity data of $\mathbf{1 , 2}$ and $\mathbf{5}$ were collected on a Bruker D8 VENTURE diffractometer at $173 \mathrm{~K}$ and data of 3-BR, 6, 7 were collected on a CCD-Bruker SMART APEX diffractometer at $203 \mathrm{~K}$. Disordered solvent molecules that could not be restrained properly were removed using the SQUEEZE routine in all data sets. Crystal data collection and refinement parameters of the X-ray diffraction studies are listed in Tables S1-S6.

In asymmetric unit of complex 1, One triflate anion was disordered and it was divided into two parts (75:25). 22 ISOR instructions were used to restrain anions, solvents and $\mathrm{Cp}^{*}$ fragments, so that there were 132 restraints in the data.

In asymmetric unit of complex 2, One triflate anion was disordered and it was divided into two parts (48:52). 36 ISOR, 2 SIMU and 30 DFIX instructions were used to restrain anions, solvents and $\mathrm{Cp}^{*}$ fragments so that there were 288 restraints in the data.

In asymmetric unit of complex $\mathbf{3}$, there were disordered anions and solvents (two triflate anions, two and a half di-isopropyl ether, five methanol and three water molecules) which could not be restrained properly. Therefore, SQUEEZE algorithm was used to omit them. One pentamethylcyclopentadienyl ligand ( $\mathrm{Cp}^{*}$ for short) was disordered and it was divided into two parts (61:39). 55 ISOR, 1 SIMU and 21 DFIX instructions were used to restrain anions, solvent and Cp* fragments so that there were 393 restraints in the data. Hydrogen of methanol molecule could not be found and others were put in calculated positions.

In asymmetric unit of complex $\mathbf{5}$, there were disordered anions and solvents (three triflate anions, two diethyl ether, six acetonitrile and four water molecules) which could not be restrained properly. Therefore, SQUEEZE algorithm was used to omit them. One triflate anion and one pentamethylcyclopentadienyl ligand ( $\mathrm{Cp} *$ for short) were disordered and they were divided into two parts (75:25 for anion and 58:42 for Cp*). 38 ISOR, 1 SIMU and 13 DFIX instructions were used to restrain anions and $\mathrm{Cp}^{*}$ fragments so that there were 247 restraints in the data.

In asymmetric unit of comlex 6, there were disordered anions and solvents (two and a half triflate anions, two dimethyl sulfoxide, twelve methanol and six water molecules) which could not be restrained properly. Therefore, SQUEEZE algorithm was used to omit them. Two triflate anions and one DMSO molecule were disordered and they were divided into two parts (67:33, 50:50 for anions and 50:50 for DMSO). 47 ISOR, 3 SIMU and 37 DFIX instructions were used to restrain anions, solvent molecule and $\mathrm{Cp}^{*}$ fragments so that there were 373 restraints in the data.

In asymmetric unit of complex 7, there were disordered solvent molecules (one diethyl ether, one methanol and one water molecules) which could not be restrained properly. Therefore, SQUEEZE algorithm was used to omit them. One triflate anion was disordered and it was divided into two parts (56:44). 35 ISOR, 1 SIMU and 17 DFIX instructions were used to restrain anions, diethyl ether and $\mathrm{Cp}^{*}$ fragments so that there were 245 restraints in the data. 
Table S3. Crystal data and structure refinement for $\mathbf{1 .}$

Empirical formula

Formula weight

Temperature

Wavelength

Crystal system

Space group

Unit cell dimensions

Volume

Z

Density (calculated)

Absorption coefficient

$\mathrm{F}(000)$

Crystal size

Theta range for data collection

Index ranges

Reflections collected

Independent reflections

Completeness to theta $=53.594^{\circ}$

Absorption correction

Max. and min. transmission

Refinement method

Data / restraints / parameters

Goodness-of-fit on $\mathrm{F}^{2}$

Final R indices [I $>2 \operatorname{sigma}(\mathrm{I})]$

$\mathrm{R}$ indices (all data)

Extinction coefficient

Largest diff. peak and hole
$\mathrm{C}_{70} \mathrm{H}_{86} \mathrm{C}_{14} \mathrm{~F}_{12} \mathrm{~N}_{12} \mathrm{O}_{14} \mathrm{Rh}_{4} \mathrm{~S}_{4}$

2229.18

173(2) K

$1.34138 \AA$

Monoclinic

P $12, /$ n 1

$\mathrm{a}=14.5778(7) \AA \quad \alpha=90^{\circ}$.

$\mathrm{b}=19.8862(9) \AA \quad \beta=111.907(2)^{\circ}$.

$\mathrm{c}=18.8713(9) \AA \quad \gamma=90^{\circ}$.

5075.7(4) $\AA^{3}$

2

$1.459 \mathrm{Mg} / \mathrm{m}^{3}$

$5.028 \mathrm{~mm}^{-1}$

2244

$0.2 \times 0.15 \times 0.05 \mathrm{~mm}^{3}$

2.871 to $54.921^{\circ}$.

$-17<=\mathrm{h}<=17,-24<=\mathrm{k}<=24,-22<=\mathrm{l}<=22$

55828

$9501[\mathrm{R}(\mathrm{int})=0.0563]$

$98.5 \%$

Semi-empirical from equivalents

0.7508 and 0.5685

Full-matrix least-squares on $\mathrm{F}^{2}$

$9501 / 0 / 555$

1.128

$\mathrm{R}_{1}=0.0534, \mathrm{wR}_{2}=0.1272$

$\mathrm{R}_{1}=0.0661, \mathrm{wR}_{2}=0.1428$

$0.00053(5)$

3.211 and -1.325 e. $\AA^{-3}$

[a] $R_{l}=\Sigma|| F_{0}|-| F_{c}||$ (based on reflections with $\left.\mathrm{F}_{0}{ }^{2}>2 \sigma \mathrm{F}^{2}\right) . w R_{2}=\left[\Sigma\left[w\left(F_{0}^{2}-F_{c}^{2}\right)^{2}\right] / \Sigma\left[w\left(F_{0}^{2}\right)^{2}\right]\right]^{1 / 2} ; w=1 /\left[\sigma^{2}\right.$ $\left.\left(F_{0}^{2}\right)+(0.095 P)^{2}\right] ; P=\left[\max \left(F_{0}^{2}, 0\right)+2 F_{c}^{2}\right] / 3\left(\right.$ also with $\left.F_{0}^{2}>2 \sigma F^{2}\right)$. 
Table S4. Crystal data and structure refinement for 2.

Empirical formula

Formula weight

Temperature

Wavelength

Crystal system

Space group

Unit cell dimensions

Volume

Z

Density (calculated)

Absorption coefficient

$\mathrm{F}(000)$

Crystal size

Theta range for data collection

Index ranges

Reflections collected

Independent reflections

Completeness to theta $=53.594^{\circ}$

Absorption correction

Max. and min. transmission

Refinement method

Data / restraints / parameters

Goodness-of-fit on $\mathrm{F}^{2}$

Final $R$ indices $[\mathrm{I}>2 \operatorname{sigma}(\mathrm{I})]^{[\mathrm{a}]}$

$\mathrm{R}$ indices (all data)

Extinction coefficient

Largest diff. peak and hole
$\mathrm{C}_{76} \mathrm{H}_{93} \mathrm{C}_{14} \mathrm{~F}_{12} \mathrm{~N}_{8} \mathrm{O}_{14.50} \mathrm{Rh}_{4} \mathrm{~S}_{4}$

2260.26

173(2) K

$1.34138 \AA$

Triclinic

P-1

$\mathrm{a}=12.2462(4) \AA \quad \alpha=91.4880(10)^{\circ}$.

$\mathrm{b}=18.9725(6) \AA \quad \beta=100.9610(10)^{\circ}$.

$\mathrm{c}=20.7122(6) \AA \quad \gamma=102.2630(10)^{\circ}$.

4605.6(2) $\AA^{3}$

2

$1.630 \mathrm{Mg} / \mathrm{m}^{3}$

$5.542 \mathrm{~mm}^{-1}$

2282

$0.500 \times 0.420 \times 0.350 \mathrm{~mm}^{3}$

3.473 to $54.894^{\circ}$.

$-14<=\mathrm{h}<=14,-23<=\mathrm{k}<=23,-25<=\mathrm{l}<=24$

59758

$17265[\mathrm{R}(\mathrm{int})=0.0555]$

$98.8 \%$

Semi-empirical from equivalents

0.751 and 0.304

Full-matrix least-squares on $\mathrm{F}^{2}$

17265 / 288 / 1225

1.055

$\mathrm{R}_{1}=0.0534, \mathrm{wR}_{2}=0.1405$

$\mathrm{R}_{1}=0.0587, \mathrm{wR}_{2}=0.1464$

$0.00144(8)$

2.055 and -1.835 e. $\AA^{-3}$

[a] $R_{l}=\Sigma|| F_{0}|-| F_{c}||$ (based on reflections with $\left.\mathrm{F}_{0}{ }^{2}>2 \sigma \mathrm{F}^{2}\right) . w R_{2}=\left[\Sigma\left[w\left(F_{0}^{2}-F_{c}^{2}\right)^{2}\right] / \Sigma\left[w\left(F_{0}^{2}\right)^{2}\right]\right]^{1 / 2} ; w=1 /\left[\sigma^{2}\right.$ $\left.\left(F_{0}^{2}\right)+(0.095 P)^{2}\right] ; P=\left[\max \left(F_{0}^{2}, 0\right)+2 F_{c}^{2}\right] / 3$ (also with $\left.F_{0}^{2}>2 \sigma F^{2}\right)$. 
Table S5. Crystal data and structure refinement for 3-BR.

Empirical formula

Formula weight

Temperature

Wavelength

Crystal system

Space group

Unit cell dimensions

Volume

Z

Density (calculated)

Absorption coefficient

$\mathrm{F}(000)$

Crystal size

Theta range for data collection

Index ranges

Reflections collected

Independent reflections

Completeness to theta $=25.242^{\circ}$

Absorption correction

Max. and min. transmission

Refinement method

Data / restraints / parameters

Goodness-of-fit on $\mathrm{F}^{2}$

Final $R$ indices $[\mathrm{I}>2 \operatorname{sigma}(\mathrm{I})]^{[\mathrm{a}]}$

$\mathrm{R}$ indices (all data)

Extinction coefficient

Largest diff. peak and hole
$\mathrm{C}_{102} \mathrm{H}_{120.67} \mathrm{~F}_{12} \mathrm{~N}_{12} \mathrm{O}_{27.67} \mathrm{Rh}_{4} \mathrm{~S}_{4}$

2725.31

203(2) K

$0.71073 \AA$

Monoclinic

$\mathrm{P} 2{ }_{1} / \mathrm{n}$

$\mathrm{a}=22.109(4) \AA$

$\alpha=90^{\circ}$.

$\mathrm{b}=32.573(6) \AA$

$\beta=101.330(4)^{\circ}$.

$\mathrm{c}=23.984(5) \AA$

$\gamma=90^{\circ}$.

16935(6) $\AA^{3}$

6

$1.603 \mathrm{Mg} / \mathrm{m}^{3}$

$0.747 \mathrm{~mm}^{-1}$

8340

$0.350 \times 0.250 \times 0.180 \mathrm{~mm}^{3}$

1.068 to $26.742^{\circ}$.

$-27<=\mathrm{h}<=24,-37<=\mathrm{k}<=41,-27<=\mathrm{l}<=30$

115016

$35618[\mathrm{R}($ int $)=0.0881]$

$99.3 \%$

Semi-empirical from equivalents

0.745 and 0.652

Full-matrix least-squares on $\mathrm{F}^{2}$

35618 / 393 / 1865

1.021

$\mathrm{R}_{1}=0.1165, \mathrm{wR}_{2}=0.3034$

$\mathrm{R}_{1}=0.1844, \mathrm{wR}_{2}=0.3517$

$0.00030(6)$

2.074 and -1.533 e. $\AA^{-3}$

[a] $R_{l}=\Sigma|| F_{0}|-| F_{c}||$ (based on reflections with $\left.\mathrm{F}_{0}{ }^{2}>2 \sigma \mathrm{F}^{2}\right) . w R_{2}=\left[\Sigma\left[w\left(F_{0}^{2}-F_{c}^{2}\right)^{2}\right] / \Sigma\left[w\left(F_{0}^{2}\right)^{2}\right]\right]^{1 / 2} ; w=1 /\left[\sigma^{2}\right.$ $\left.\left(F_{0}^{2}\right)+(0.095 P)^{2}\right] ; P=\left[\max \left(F_{0}^{2}, 0\right)+2 F_{c}^{2}\right] / 3$ (also with $\left.F_{0}^{2}>2 \sigma F^{2}\right)$. 
Table S6. Crystal data and structure refinement for $\mathbf{5}$.

Empirical formula

Formula weight

Temperature

Wavelength

Crystal system

Space group

Unit cell dimensions

Volume

Z

Density (calculated)

Absorption coefficient

$\mathrm{F}(000)$

Crystal size

Theta range for data collection

Index ranges

Reflections collected

Independent reflections

Completeness to theta $=53.594^{\circ}$

Absorption correction

Max. and min. transmission

Refinement method

Data / restraints / parameters

Goodness-of-fit on $\mathrm{F}^{2}$

Final $R$ indices $[\mathrm{I}>2 \operatorname{sigma}(\mathrm{I})]^{[\mathrm{a}]}$

$\mathrm{R}$ indices (all data)

Extinction coefficient

Largest diff. peak and hole
$\mathrm{C}_{104} \mathrm{H}_{106.67} \mathrm{~F}_{12} \mathrm{~N}_{25.33} \mathrm{O}_{28} \mathrm{Pd}_{2} \mathrm{Rh}_{4} \mathrm{~S}_{4}$

3140.15

173(2) K

$1.34138 \AA$

Triclinic

P-1

$\mathrm{a}=22.226(3) \AA$

$\alpha=61.751(5)^{\circ}$.

$\mathrm{b}=22.561(3) \AA$

$\beta=83.713(5)^{\circ}$.

$\mathrm{c}=23.443(3) \AA$

$\gamma=67.618(4)^{\circ}$.

9539(2) $\AA^{3}$

3

$1.640 \mathrm{Mg} / \mathrm{m}^{3}$

$5.250 \mathrm{~mm}^{-1}$

4728

$0.400 \times 0.370 \times 0.350 \mathrm{~mm}^{3}$

1.868 to $59.998^{\circ}$.

$-28<=\mathrm{h}<=28,-29<=\mathrm{k}<=28,-30<=\mathrm{l}<=30$

136736

$42320[\mathrm{R}($ int $)=0.0715]$

$99.6 \%$

Semi-empirical from equivalents

0.374 and 0.187

Full-matrix least-squares on $\mathrm{F}^{2}$

42320 / 247 / 2019

1.051

$\mathrm{R}_{1}=0.0614, \mathrm{wR}_{2}=0.1698$

$\mathrm{R}_{1}=0.0816, \mathrm{wR}_{2}=0.1877$

$0.00054(3)$

1.091 and -1.202 e. $\AA^{-3}$

[a] $R_{l}=\Sigma|| F_{0}|-| F_{c}||$ (based on reflections with $\left.\mathrm{F}_{0}{ }^{2}>2 \sigma \mathrm{F}^{2}\right) . w R_{2}=\left[\Sigma\left[w\left(F_{0}^{2}-F_{c}^{2}\right)^{2}\right] / \Sigma\left[w\left(F_{0}^{2}\right)^{2}\right]\right]^{1 / 2} ; w=1 /\left[\sigma^{2}\right.$ $\left.\left(F_{0}^{2}\right)+(0.095 P)^{2}\right] ; P=\left[\max \left(F_{0}^{2}, 0\right)+2 F_{c}^{2}\right] / 3\left(\right.$ also with $\left.F_{0}^{2}>2 \sigma F^{2}\right)$ 
Table S7. Crystal data and structure refinement for 6.

Empirical formula

Formula weight

Temperature

Wavelength

Crystal system

Space group

Unit cell dimensions

Volume

Z

Density (calculated)

Absorption coefficient

$\mathrm{F}(000)$

Crystal size

Theta range for data collection

Index ranges

Reflections collected

Independent reflections

Completeness to theta $=25.242^{\circ}$

Absorption correction

Max. and min. transmission

Refinement method

Data / restraints / parameters

Goodness-of-fit on $\mathrm{F}^{2}$

Final $R$ indices $[\mathrm{I}>2 \operatorname{sigma}(\mathrm{I})]^{[\mathrm{a}]}$

$\mathrm{R}$ indices (all data)

Extinction coefficient

Largest diff. peak and hole
$\mathrm{C}_{104} \mathrm{H}_{140} \mathrm{~F}_{12} \mathrm{~N}_{12} \mathrm{O}_{38} \mathrm{Pd}_{2} \mathrm{Rh}_{4} \mathrm{~S}_{6}$

3211.07

203(2) K

$0.71073 \AA$

Monoclinic

$\mathrm{C} 2 / \mathrm{c}$

$$
\begin{array}{ll}
\mathrm{a}=42.412(9) \AA & \alpha=90^{\circ} . \\
\mathrm{b}=24.783(5) \AA & \beta=93.396(4)^{\circ} . \\
\mathrm{c}=37.548(8) \AA & \gamma=90^{\circ} .
\end{array}
$$

39397(14) $\AA^{3}$

12

$1.624 \mathrm{Mg} / \mathrm{m}^{3}$

$0.952 \mathrm{~mm}^{-1}$

19536

$0.560 \times 0.440 \times 0.320 \mathrm{~mm}^{3}$

0.952 to $26.784^{\circ}$.

$-53<=\mathrm{h}<=53,-31<=\mathrm{k}<=29,-46<=\mathrm{l}<=47$

129831

$41408[\mathrm{R}($ int $)=0.0896]$

$99.4 \%$

Semi-empirical from equivalents

0.745 and 0.296

Full-matrix least-squares on $\mathrm{F}^{2}$

41408 / 373 / 2012

1.034

$\mathrm{R}_{1}=0.0923, \mathrm{wR}_{2}=0.2458$

$\mathrm{R}_{1}=0.1613, \mathrm{wR}_{2}=0.3084$

$\mathrm{n} / \mathrm{a}$

2.278 and -1.552 e. $\AA^{-3}$

[a] $R_{l}=\Sigma|| F_{0}|-| F_{c}||$ (based on reflections with $\left.\mathrm{F}_{0}^{2}>2 \sigma \mathrm{F}^{2}\right) . w R_{2}=\left[\Sigma\left[w\left(F_{0}^{2}-F_{c}^{2}\right)^{2}\right] / \Sigma\left[w\left(F_{0}^{2}\right)^{2}\right]\right]^{1 / 2} ; w=1 /\left[\sigma^{2}\right.$ $\left.\left(F_{0}^{2}\right)+(0.095 P)^{2}\right] ; P=\left[\max \left(F_{0}^{2}, 0\right)+2 F_{c}^{2}\right] / 3$ (also with $\left.F_{0}^{2}>2 \sigma F^{2}\right)$ 
Table S8. Crystal data and structure refinement for 7.

Empirical formula

Formula weight

Temperature

Wavelength

Crystal system

Space group

Unit cell dimensions

Volume

Z

Density (calculated)

Absorption coefficient

$\mathrm{F}(000)$

Crystal size

Theta range for data collection

Index ranges

Reflections collected

Independent reflections

Completeness to theta $=25.242^{\circ}$

Absorption correction

Max. and min. transmission

Refinement method

Data / restraints / parameters

Goodness-of-fit on $\mathrm{F}^{2}$

Final $R$ indices $[\mathrm{I}>2 \operatorname{sigma}(\mathrm{I})]^{[\mathrm{a}]}$

$\mathrm{R}$ indices (all data)

Extinction coefficient

Largest diff. peak and hole
$\mathrm{C}_{89} \mathrm{H}_{102} \mathrm{Cl}_{4} \mathrm{~F}_{12} \mathrm{~N}_{12} \mathrm{O}_{24} \mathrm{Rh}_{4} \mathrm{~S}_{4}$

2633.50

203(2) K

$0.71073 \AA$

Monoclinic

$\mathrm{P} 2{ }_{1} / \mathrm{n}$

$\mathrm{a}=24.819(7) \AA$

$\alpha=90^{\circ}$.

$\mathrm{b}=15.641(5) \AA$

$\beta=103.341(5)^{\circ}$.

$\mathrm{c}=29.158(8) \AA$

$\gamma=90^{\circ}$.

11013(6) $\AA^{3}$

4

$1.588 \mathrm{Mg} / \mathrm{m}^{3}$

$0.854 \mathrm{~mm}^{-1}$

5328

$0.680 \times 0.650 \times 0.220 \mathrm{~mm}^{3}$

1.625 to $26.499^{\circ}$.

$-31<=\mathrm{h}<=31,-12<=\mathrm{k}<=19,-36<=\mathrm{l}<=34$

73005

$22703[\mathrm{R}($ int $)=0.0561]$

$99.3 \%$

Semi-empirical from equivalents

0.801 and 0.687

Full-matrix least-squares on $\mathrm{F}^{2}$

22703 / 245 / 1365

1.015

$\mathrm{R}_{1}=0.0601, \mathrm{wR}_{2}=0.1584$

$\mathrm{R}_{1}=0.1022, \mathrm{wR}_{2}=0.1878$

$\mathrm{n} / \mathrm{a}$

1.253 and -0.829 e. $\AA^{-3}$

[a] $R_{l}=\Sigma|| F_{0}|-| F_{c} \|$ (based on reflections with $\left.\mathrm{F}_{0}^{2}>2 \sigma \mathrm{F}^{2}\right) . w R_{2}=\left[\Sigma\left[w\left(F_{0}^{2}-F_{c}^{2}\right)^{2}\right] / \Sigma\left[w\left(F_{0}^{2}\right)^{2}\right]\right]^{1 / 2} ; w=1 /\left[\sigma^{2}\right.$ $\left.\left(F_{0}^{2}\right)+(0.095 P)^{2}\right] ; P=\left[\max \left(F_{0}^{2}, 0\right)+2 F_{c}^{2}\right] / 3$ (also with $\left.F_{0}^{2}>2 \sigma F^{2}\right)$. 


\section{References.}

(S1) Gao, W.-X.; Lin, Y.-J.; Jin G.-X. Stepwise construction of discrete parallelogram- and prismshaped organometallic architectures based on half-sandwich rhodium fragments. Dalton Trans. 2017, 46, 10498-10503;

(S2) Farha, O. K.; Malliakas, C. D.; Kanatzidis, M. G.; Hupp, J. T. Control over Catenation in Metal-Organic Frameworks via Rational Design of the Organic Building Block. J. Am. Chem. Soc. 2010, 132, 950-952;

(S3) Huang, S.-L.; Lin, Y.-J.; Hor, T. S. A.; Jin, G.-X.; Cp*Rh-Based Heterometallic Metallarectangles: Size-Dependent Borromean Link Structures and Catalytic Acyl Transfer. $J$. Am. Chem. Soc. 2013, 135, 8125-8128;

(S4) Knall, A.-C.; Slugovc, C. Inverse electron demand Diels-Alder (iEDDA)-initiated conjugation: a (high) potential click chemistry scheme. Chem. Soc. Rev. 2013, 42, 5131-5142;

(S5) Foster, R. A. A.; Willis, M. C. Tandem inverse-electron-demand hetero-/retro-Diels-Alder reactions for aromatic nitrogen heterocycle synthesis. Chem. Soc. Rev. 2013, 42, 63-76;

(S6) Junquera, J.; Paz, O.; Sanchez-Portal, D.; Artacho, E. Numerical atomic orbitals for linearscaling calculations. Phys. Rev. B 2001, 64, 235111;

(S7) Troullier, N.; Martins, J. L. Efficient pseudopotentials for plane-wave calculations. Phys. Rev. B 1991, 43, 1993-2006;

(S8) Perdew, J. P.; Burke, K.; Ernzerhof, M. Generalized Gradient Approximation Made Simple. Phys. Rev. Lett. 1996, 77, 3865-3868;

(S9) Grimme, S., Semiempirical GGA-type density functional constructed with a long-range dispersion correction. J. Comput. Chem. 2006, 27, 1787-1799. 